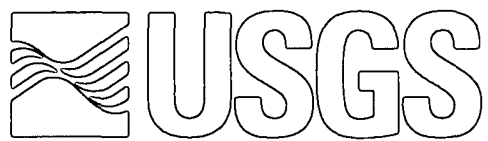

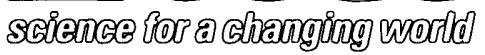

Prepared in cooperation with CITY OF NEWTON, IOWA

\title{
Ground Water Near Newton, Jasper County, lowa
}

Water-Resources Investigations Repurt 01-4148 



\title{
Ground Water Near Newton, Jasper County, lowa
}

\author{
By ROBERT C. BUCHMILLER
}

Water-Resources Investigations Report 01-4148

Prepared in cooperation with the CITY OF NEWTON, IOWA

lowa City, lowa

2001 


\section{U.S. Department of the Interior \\ Gale A. Norton, Secretary}

\section{U.S. Geological Survey}

Charles G. Groat, Director

Any use of trade, product, or firm names in this publication is for descriptive purposes only and does not imply endorsement by the U.S. Government.

For additional information write to:

\section{District Chief}

U.S. Geological Survey

P.O. Box 1230

400 S. Clinton St., Rm. 269

lowa City, IA 52244-1230
Copies of this report can be purchased from:

U.S. Geological Survey

Information Services

Building 810

Box 25286, Federal Center

Denver, C0 80225-0286 


\section{CONTENTS}

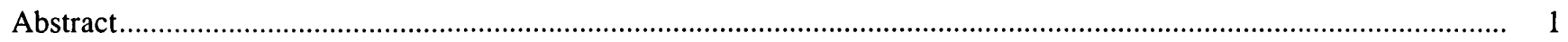

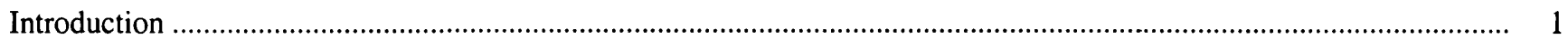

Purpose and Scope

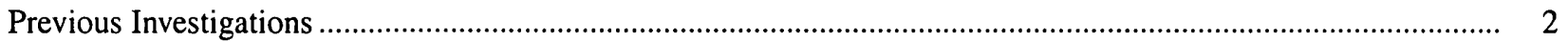

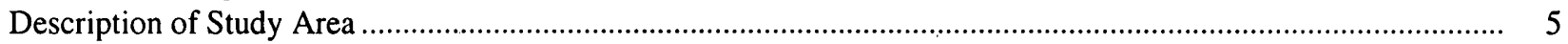

Acknowledgments ................................................................................................................................. 5

Description of South Skunk River Alluvial Deposits Near Newton .............................................................................. 5

Collection of Seismic-Refraction and Observation-Well Data ............................................................................. 5

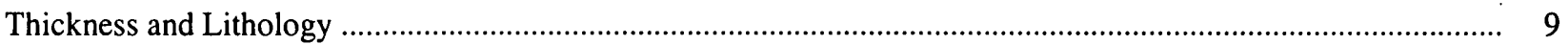

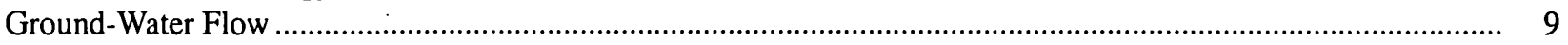

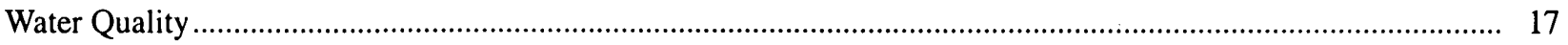

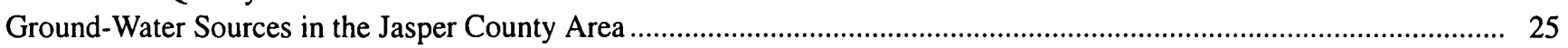

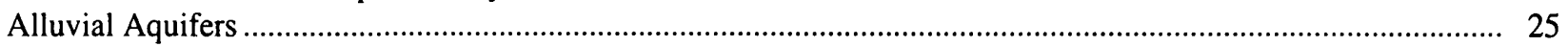

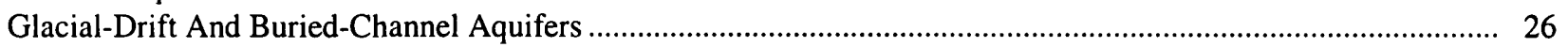

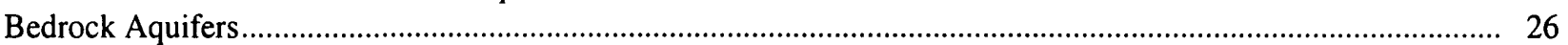

Summary

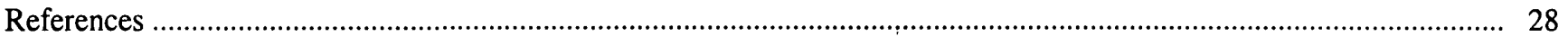

FIGURES

1. Maps showing location of Jasper County and Newton study area in Iowa .................................................... 3

2. Map showing location of data-collection sites in South Skunk River Valley near Newton, Iowa ........................ 4

3. Geologic sections $A-A^{\prime}$ through $L-L^{\prime}$ based on seismic-refraction and test-hole data ......................................... 8

4-6. Maps showing:

4. Altitude and configuration of bedrock surface based on seismic-refraction and test-hole data, South Skunk River Valley near Newton, Iowa ............................................................................................... 18

5. Thickness of unconsolidated deposits based on seismic-refraction and test-hole data, South Skunk

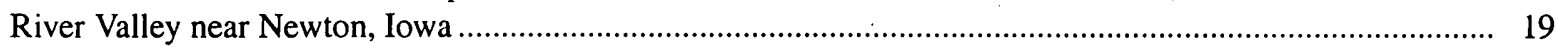

6. Potentiometric surface of alluvial aquifer, South Skunk River Valley near Newton, Iowa, June 6, 2000........ 21

\section{TABLES}

1. Description of hydrogeologic units in central Iowa

2. Description of drilled test holes and geologic information ...................................................................... 10

3. Static water-level measurements from observation wells, municipal wells, and surface-water sites in the South Skunk River alluvium near Newton, Iowa, February, June, and October 2000

4. Selected water-quality characteristics and constituents in water from selected wells in the South Skunk River alluvial aquifer near Newton, Iowa, 2000 
CONVERSION FACTORS, ABBREVIATIONS, AND VERTICAL DATUM

\begin{tabular}{|c|c|c|}
\hline Multiply & By & To obtain \\
\hline \multicolumn{3}{|c|}{ Length } \\
\hline inch (in.) & 2.54 & centimeter \\
\hline foot $(f t)$ & 0.3048 & meter \\
\hline mile (mi) & 1.609 & kilometer \\
\hline \multicolumn{3}{|c|}{ Area } \\
\hline acre & 4,047 & square meter \\
\hline square mile $\left(\mathrm{mi}^{2}\right)$ & 2.590 & square kilometer \\
\hline \multicolumn{3}{|c|}{ Volume } \\
\hline cubic foot $\left(\mathrm{ft}^{3}\right)$ & 28.32 & liter \\
\hline gallon (gal) & 3.785 & liter \\
\hline million gallons (Mgal) & 3,785 & cubic meter \\
\hline \multicolumn{3}{|c|}{ Flow } \\
\hline cubic foot per second $\left(\mathrm{ft}^{3} / \mathrm{s}\right)$ & 0.02832 & cubic meter per second \\
\hline foot per second $(\mathrm{ft} / \mathrm{s})$ & 0.3048 & meter per second \\
\hline gallon per minute ( $\mathrm{gal} / \mathrm{min})$ & 0.06308 & liter per second \\
\hline million gallons per day (Mgal/d) & 3,785 & cubic meter per day \\
\hline
\end{tabular}

\begin{abstract}
Abbreviated water-quality units used in this report: Chemical concentrations are reported in milligrams per liter $(\mathrm{mg} / \mathrm{L})$ and micrograms per liter $(\mu \mathrm{g} / \mathrm{L})$. A milligram per liter expresses the concentration of chemical constituents in solution as weight (milligrams) of solute per unit volume (liter) of water. A microgram per liter expresses the concentration of chemical constituents in solution as weight (micrograms) of solute per unit volume (liter) of water. Microsiemens per centimeter $(\mu \mathrm{S} / \mathrm{cm})$ at 25 degrees Celsius $\left({ }^{\circ} \mathrm{C}\right)$ expresses the capability of a unit volume of water to conduct an applied electrical current.
\end{abstract}

Sea level: In this report, "sea level" refers to the National Geodetic Vertical Datum of 1929 (NGVD of 1929)-a geodetic datum derived from a general adjustment of the first-order level nets of both the United States and Canada, formerly called the "Sea Level Datum of 1929."

Altitude: As used in this report, "altitude" refers to distance above or below sea level. 


\title{
Ground Water Near Newton, Jasper County, lowa
}

\author{
By Robert C. Buchmiller
}

\section{Abstract}

The U.S. Geological Survey, in cooperation with the city of Newton, Iowa, conducted an investigation of the ground-water resources of Jasper County, Iowa, near Newton during 1999-2001. The purpose of the investigation was to provide additional information on the South Skunk River alluvial aquifer from which Newton obtains its present municipal supply and to summarize the available information on other groundwater resources in the county.

The South Skunk River alluvial aquifer consists of unconsolidated deposits of sand and gravel of glacial and fluvial origin. These deposits overlie bedrock composed primarily of shale and limestone of Pennsylvanian or Mississippian age. Information on the South Skunk River alluvial aquifer and other Jasper County alluvial aquifers is limited to a few test holes in a few locations. Additional thickness and lithologic information was collected using seismic refraction and testhole drilling to increase the understanding of the South Skunk River alluvial aquifer near Newton. Water-level and water-quality information also was collected.

The alluvial deposits along the South Skunk River near Newton range from less than 30 to more than 60 feet thick. Three areas of deposits exceeding 60 feet thick occur near the present city of Newton well field-about 5,000 feet west of the present well field, at the present well field, and about 5,000 feet southeast of the present well field.

Ground water in the South Skunk River alluvial aquifer near the Newton well field flows toward the municipal well field. Ground-water levels on the well-field side of the South Skunk
River were lower than water levels in the river, indicating flow from the river toward the well field.

The water quality in the South Skunk River and the alluvial aquifer was similar, except most ground-water samples contained low dissolvedoxygen concentrations. The low dissolved-oxygen concentrations in ground water resulted in high concentrations of iron and manganese in some locations and reduced forms of nitrogen.

\section{INTRODUCTION}

The city of Newton, Iowa, obtains its municipal water supply from the alluvial sand and gravel aquifer along the South Skunk River. Twenty-one wells ranging in depth from 44 to $57 \mathrm{ft}$ are completed in the alluvial aquifer about $5 \mathrm{mi}$ southwest of the city. Each well yields between 100 and $700 \mathrm{gal} / \mathrm{min}$ of water. During the summer of 2000 , an additional well was drilled to underlying bedrock and completed in the Jordan aquifer for municipal water supply.

Additional water-supply wells in a new well field may be required by the city of Newton during the next 10 years to meet future demand from commercial, industrial, and domestic users. Average daily groundwater withdrawals for municipal needs are expected to increase from $4.5 \mathrm{Mgal} / \mathrm{d}$ in 1998 to $8 \mathrm{Mgal} / \mathrm{d}$ by 2007 (M. Hoffert, city of Newton, oral commun., May 1998).

To help address concerns about future sources of water supply, the U.S. Geological Survey (USGS), in cooperation with the city of Newton, conducted a study from 1999 to 2001 to provide information about the sources of ground water (unconsolidated and bedrock aquifers) in Jasper County, particularly in the Newton area. The objectives of the study were to: (1) describe the thickness, lithology, and water quality of the unconsolidated alluvial deposits in the South 
Skunk River Valley in the Newton area, and (2) briefly summarize available information on ground-water resources in the Jasper County area.

\section{Purpose and Scope}

The purpose of this report is to describe results of the study on ground-water sources in the Newton and Jasper County area (fig. 1). Available hydrologic and geologic information was compiled from the scientific literature and previous studies. New thickness, lithologic, and water-quality data for unconsolidated alluvial deposits were collected for this study from October 1999 through October 2000 from a part of the South Skunk River Valley near Newton's present municipal supply (fig. 2) and are presented in this report.

Information from this study will contribute to understanding the characterization and flow-system definition of local and regionally important alluvial aquifers. Collection of hydrogeologic data from alluvial aquifers will enhance databases needed for understanding and constructing flow models for simulating interactions between ground and surface water, furnish results needed by managers for planning and operation of public-water supplies, and provide information that is transferable to present and (or) future public-water supplies utilizing alluvial aquifer sources.

\section{Previous Investigations}

Few studies have been conducted that are related to the water resources associated with the unconsolidated deposits in the study area. The geology, physiography, and drainage of Jasper County are described in Williams (1904). Norton and others (1912) describe the water resources of Jasper County, including the study area: Information on the occurrence, availability, quality, and utilization of water in central Iowa is presented in Twenter and Coble (1965). The bedrock topography of central Iowa is mapped by Hansen (1985). Bruner and Hallberg (1987) describe the ground-water quality of the entire Skunk River Basin, particularly with regard to the occurrence of nitrate. Information about water quality and geology is available for the Mississippian aquifer (Horick and Steinhilber, 1973), the Silurian-Devonian aquifer (Horick, 1984), and the Jordan aquifer (part of the CambrianOrdovician aquifer system) (Horick and Steinhilber,
1978). The recharge to, and ground-water movement in, the St. Peter and Jordan aquifers are evaluated by Burkart and Buchmiller (1990). A comprehensive summary of geology and hydrologic characteristics for the major aquifers in Iowa is presented by Olcott (1992).

A geological and geophysical study of a small area of the flood plain near the Newton well fields was conducted by Lyle Sendlein in 1969 (L. Sendlein, written commun., June 1969). The objective of the study was to determine the altitude of the bedrock surface beneath the flood plain. Areas that appeared to be deeper to bedrock were believed to contain greater thicknesses of sand and gravel. Fifteen depth-tobedrock determinations were made at selected locations using seismic-refraction techniques. From these interpretations, well logs, and rock outcrops, the altitude of the bedrock surface in the flood plain was mapped. The study concluded that the thickness of the alluvium is relatively uniform and that $47 \mathrm{ft}( \pm 10 \mathrm{ft})$ of sand and gravel overlie the bedrock.

Areas of the South Skunk River alluvial aquifer near the present municipal supply wells have been investigated by the city of Newton to determine the occurrence of sand and gravel deposits of sufficient thickness to construct additional municipal wells. Sixteen test holes were drilled in 1980 at selected locations southwest and southeast of the present well fields (Layne-Western Company, Inc., written commun., 1980). Results from this drilling indicated a highly variable thickness of sand and gravel and varying types of materials underlying the alluvial aquifer. Six of the test holes indicated limestone as the uppermost bedrock underlying the aquifer. Seven test holes penetrated shale beneath the alluvial aquifer. The remaining three test holes indicated clay or glacial till underlying the aquifer. Depths to bedrock varied from 42 to $66 \mathrm{ft}$ below land surface. Thicknesses of sand and gravel ranged from 25 to $49 \mathrm{ft}$. Some well logs reported encountering wood, coal, or other vegetative debris within the aquifer.

Two additional test holes were drilled in 1998 southeast of the well fields (Northway Well and Pump Co., written commun., 1998). One test hole reported shale underlying the alluvial aquifer, whereas the second reported limestone. Depths to bedrock were 53 and $44 \mathrm{ft}$, respectively. Sand and gravel thicknesses were 27 and $32 \mathrm{ft}$, respectively. 


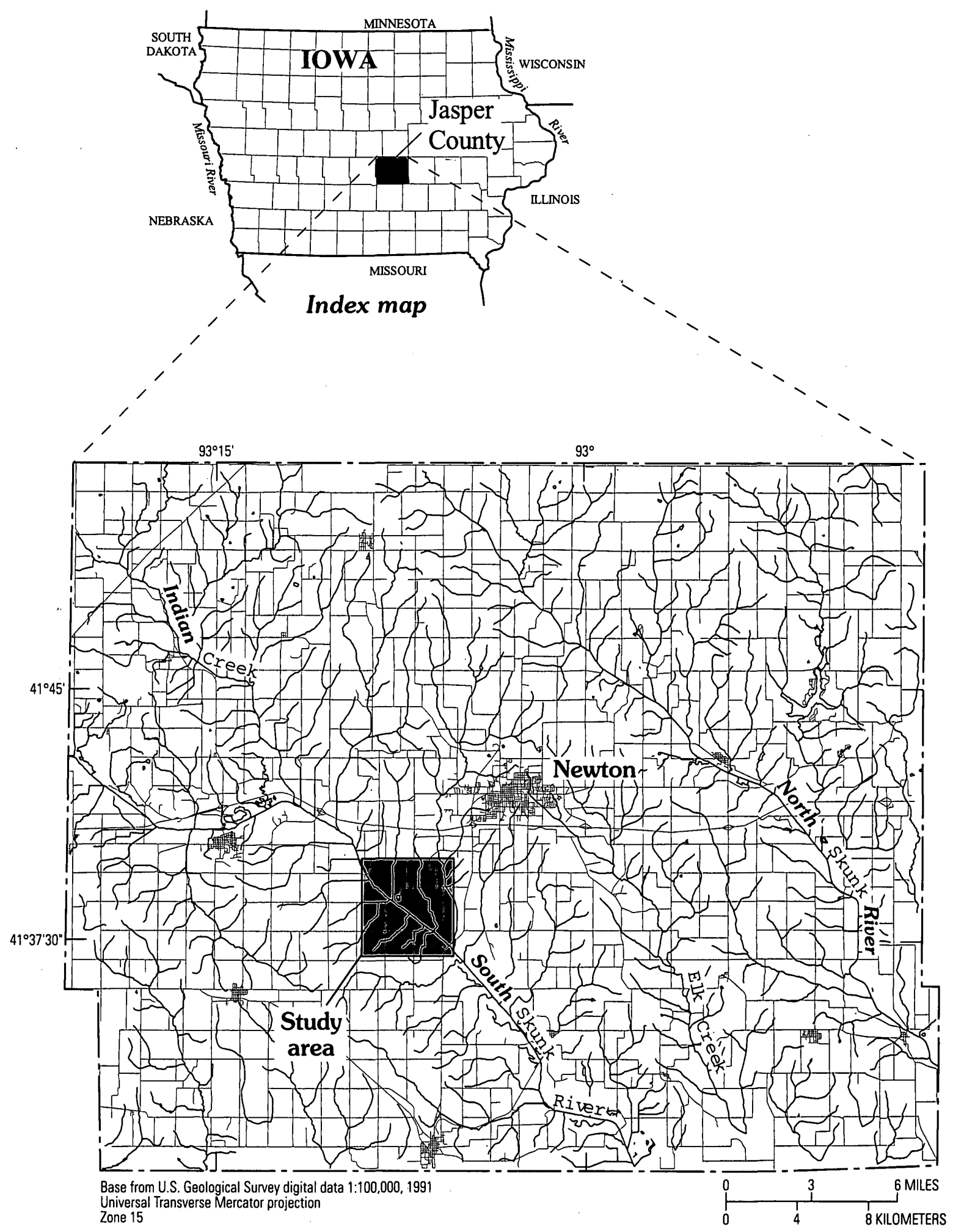

Figure 1. Location of Jasper County and Newton study area in lowa. 


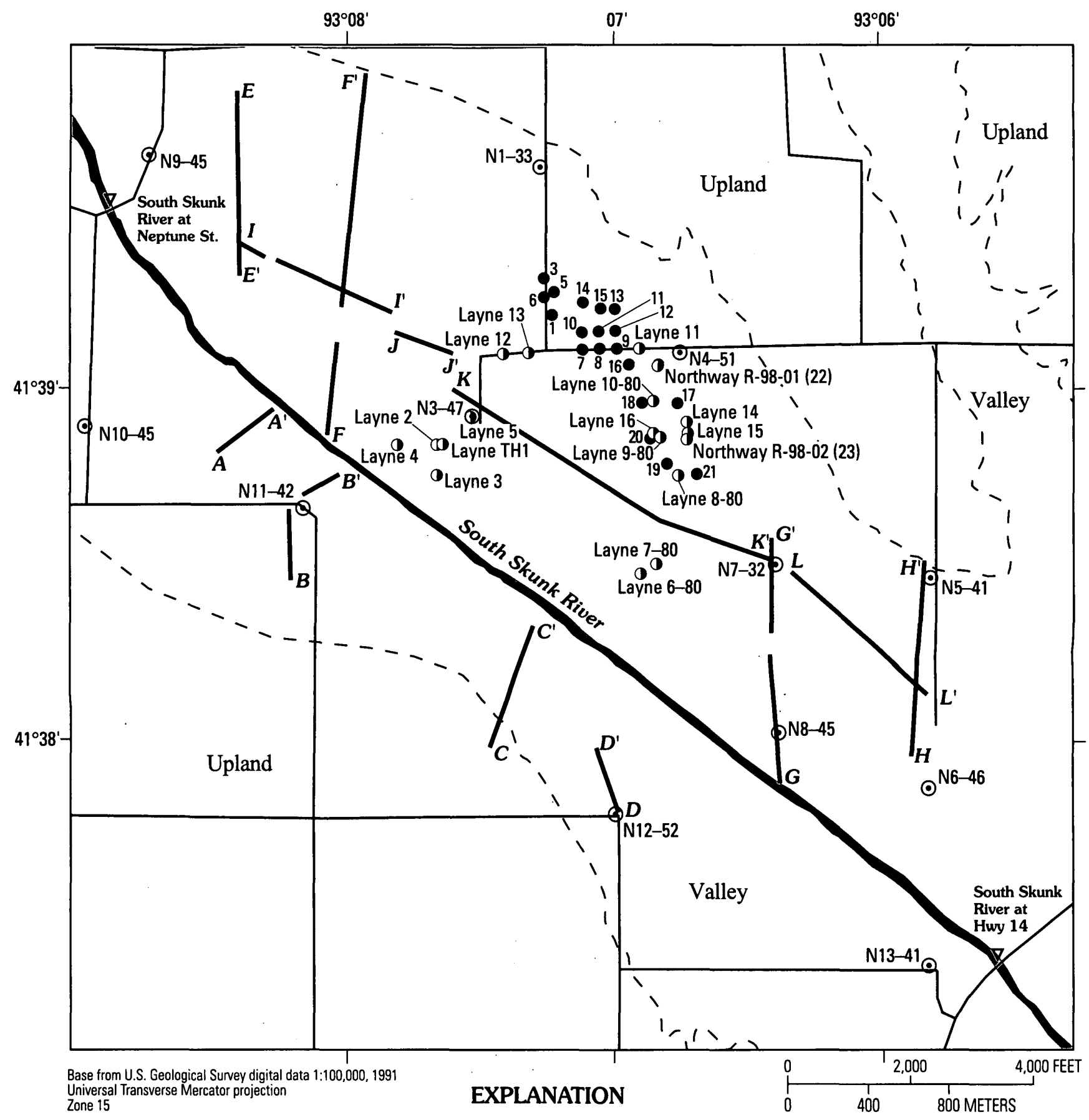

Data-collection sites

Layne 130 Test hole and identifier

19. Municipal well and identifier

N12-52॰ USGS test hole/observation well and identifier

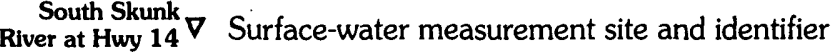

A $A^{\prime}$ Trace of seismic geophysical section

$A-A^{\prime}$ through $L-L^{\prime}$

- - Boundary between upland area and river valley

Figure 2. Location of data-collection sites in South Skunk Valley near Newton, lowa. 


\section{Description of Study Area}

Newton, Iowa, is located on the rolling, dissected uplands of the Southern Iowa Drift Plain in Jasper County (Prior, 1991). The city is located in the approximate center of the county and lies about $5 \mathrm{mi}$ northeast of the South Skunk River Valley. The South Skunk River, one of two major drainage systems that receive runoff from Jasper County, drains about onehalf of the county and originates in north-central Iowa. The other major drainage system, north and east of Newton, is the North Skunk River, which receives runoff from about one-third of the county. The two rivers join about $45 \mathrm{mi}$ southeast of Jasper County before continuing on to the southeast to join the Mississippi River. Small areas in the southwest and northeast corners of the county drain to the Des Moines and Iowa Rivers, respectively.

The topography of Jasper County is dominated by steeply rolling hills eroded into glacial drift. Valleys of large rivers contain significant deposits of alluvial material. The thickness of the unconsolidated surficial deposits ranges from zero in small areas in the deeper river valleys where bedrock is exposed to about $200 \mathrm{ft}$ beneath upland areas. The underlying bedrock consists of a thick sequence of sedimentary rocks. This geologic framework contains the hydrogeologic units described in table 1.

An area of about $9.6 \mathrm{mi}^{2}$ along the South Skunk River Valley southwest of Newton was selected for additional data collection during this study (fig. 1). The South Skunk River Valley is about 1.5 to $2 \mathrm{mi}$ wide in the study area. The land-surface altitude of the river valley in this area varies from about 765 to. $775 \mathrm{ft}$ above sea level, and adjacent upland areas rise to about $900 \mathrm{ft}$. The South Skunk River in this area was channelized and straightened during the first quarter of the 20th century.

Streamflow in the South Skunk River is measured about $6 \mathrm{mi}$ upstream from the study area at the USGS streamflow-gaging station South Skunk River at Colfax (station 0547:1050) ${ }^{1}$. Annual mean daily streamflow at this site is about $622 \mathrm{ft}^{3} / \mathrm{s}$ (October 1985 through September 2000). However, during October 1999 through September 2000, mean daily streamflow averaged $96.3 \mathrm{ft}^{3} / \mathrm{s}$ due to less-than-normal

\footnotetext{
${ }^{1}$ Real-time stage and discharge data for this stream-gaging station can be accessed through the Internet at URL http://ia.usgs.gov/data.html.
}

precipitation in central Iowa (Nalley and others, 2001).

\section{Acknowledgments}

The author thanks the city of Newton Waterworks staff for their assistance in gathering technical information and assisting in data collection. The author also thanks Peter Schulmeyer, Aimee Donnelly, and Dan Christiansen, USGS, for assisting with data collection and compilation. The author is grateful to landowners in the Newton area who granted access to their property for collection of data.

\section{DESCRIPTION OF SOUTH SKUNK RIVER ALLUVIAL DEPOSITS NEAR NEWTON}

The alluvial deposits associated with the South Skunk River Valley near Newton consist of stratified sand and gravel deposits of glacial and fluvial origin. The upper $20 \mathrm{ft}$ of the alluvial deposits are interbedded with clay and silt lenses and overlain by a developed soil horizon. Alluvial deposits below a depth of about $20 \mathrm{ft}$ typically become coarser with depth. Although all the unconsolidated materials described in available geologic logs could be expected to yield water, only those materials that are described as having a "medium" sand or larger-grained material are considered to be the alluvial aquifer for the purposes of this report. Therefore, the thickness of the alluvial aquifer, in general, is considered to be the amount of sand and gravel between about $20 \mathrm{ft}$ below land surface and the top of the bedrock surface.

\section{Collection of Seismic-Refraction and Observation-Well Data}

Seismic refraction and observation-well drilling were used by the USGS to collect new geologic information for the unconsolidated deposits in the study area. Seismic refraction was used to determine the depth to bedrock below land surface and to estimate the thickness of unconsolidated deposits. Observation wells and test holes that penetrated the alluvium were used to provide additional geologic information and to provide verification of the seismic interpretations at selected locations. Observation wells also were 
Table 1. Description of hydrogeologic units in central lowa

\begin{tabular}{|c|c|c|c|c|}
\hline Hydrogeologic unit' & $\begin{array}{l}\text { Approximate thickness in } \\
\text { central Jasper County } \\
\text { (feet) })^{1}\end{array}$ & Age of rock unit ${ }^{2}$ & $\begin{array}{l}\text { Potential well yield } \\
\text { (gallons per minute) }\end{array}$ & Lithology 1 \\
\hline $\begin{array}{l}\text { Alluvial, glacial-drift, and buried- } \\
\text { channel aquifers }\end{array}$ & $0-100$ & Quaternary & Less than 20 to more than 500 & $\begin{array}{l}\text { Sand, gravel, silt, clay, } \\
\text { and boulders. }\end{array}$ \\
\hline Confining unit & $50-100$ & Pennsylvanian & Very small & $\begin{array}{l}\text { Shale, sandstone, thin } \\
\text { limestone, and coal. }\end{array}$ \\
\hline Mississippian aquifer & $250-300$ & Mississippian & Less than 20 to 50 & $\begin{array}{l}\text { Limestone, dolomite, } \\
\text { and shale (gypsum } \\
\text { and anhydrite occur } \\
\text { locally). }\end{array}$ \\
\hline Confining unit & $200-250$ & $\begin{array}{l}\text { Mississippian } \\
\text { and } \\
\text { Devonian }\end{array}$ & Very small & $\begin{array}{l}\text { Shale, siltstone, } \\
\text { limestone, and } \\
\text { dolomite. }\end{array}$ \\
\hline Devonian aquifer & $500-550$ & Devonian & Less than 20 & $\begin{array}{l}\text { Limestone, dolomite, } \\
\text { and shale. }\end{array}$ \\
\hline Confining unit & $500-550$ & $\begin{array}{l}\text { Silurian } \\
\text { and } \\
\text { Ordovician }\end{array}$ & Very small & $\begin{array}{l}\text { Dolomite, shale, chert, } \\
\text { limestone, and } \\
\text { sandstone. }\end{array}$ \\
\hline $\begin{array}{c}\text { Cambrian-Ordovician System } \\
\text { St. Peter aquifer } \\
\text { Jordan aquifer }\end{array}$ & $\begin{array}{c}500-550 \\
30-40 \\
40-50\end{array}$ & $\begin{array}{l}\text { Ordovician and } \\
\text { Cambrian }\end{array}$ & More than 1,000 & Sandstone and dolomite. \\
\hline Confining unit & $350-550$ & Cambrian & Very small & $\begin{array}{l}\text { Sandstone, shale, } \\
\text { siltstone, and } \\
\text { dolomite. }\end{array}$ \\
\hline
\end{tabular}

'Modified from Twenter and Coble (1965).

${ }^{2}$ Age classification of rock units are those of the lowa Department of Natural Resources, Geological Survey Bureau.

constructed to provide for collection of water-level measurements and water-quality samples.

Using the seismic-refraction method, the contact between alluvium and bedrock is determined from a contrast in seismic acoustic velocity. Seismicrefraction velocities ranged from less than $1,000 \mathrm{ft} / \mathrm{s}$ in unsaturated unconsolidated materials to about $12,000 \mathrm{ft} / \mathrm{s}$ in the bedrock. The refraction system consisted of a 12-channel seismograph, geophones (receivers), an energy source, and related equipment. Geophones were placed in lines as much as $1,100 \mathrm{ft}$ long in the areas of interest, and seismic energy was supplied by detonating an explosive mixture of ammonium nitrate and nitromethane. Data were recorded on seismograms and then downloaded onto computer disk. Onsite calculations of the data, made on the basis of equations given by Haeni (1988), were used to maximize the quality of data-collection geometries. Final processing of the data was done using a modeling program, SIPT2V4.1 (Rimrock Geophysics, Inc., 1995) assuming a three-layer system-unsaturated unconsolidated materials, saturated unconsolidated materials, and bedrock. An assumption of the modeling program is that refraction acoustic velocities increase with depth. More than 35,000 linear $\mathrm{ft}$ of seismic-refraction data were collected during October-November 1999. Seismic-refraction data were collected at sections $A-A^{\prime}$ through $L-L$ ' shown in figure 3 . The latitude and longitude of the seismic shot points along each seismic section were determined by a global positioning system (GPS).

A total of 12 test holes were drilled by the USGS during the study (fig. 2), with an average depth of $44 \mathrm{ft}$. All test holes were drilled with 3.25-in. insidediameter (ID) hollow-stem augers. Test holes were drilled to bedrock or to the limits of the drill rig being used. Samples of auger cuttings were collected at major lithologic changes. Observation wells were constructed at the test-hole locations by lowering $2.5 \mathrm{ft}$ of 0.020 -in. slot-size, polyvinyl chloride (PVC) schedule 40, flush-threaded, 2-in. diameter well screens and riser pipe inside the auger flights. Wells were installed near the bottom of the sand and gravel deposits overlying the bedrock. The annular space around the screen and riser was filled with native materials to within about $8 \mathrm{ft}$ of land surface. The upper $8 \mathrm{ft}$ were filled with bentonite clay and cement to prevent surface runoff from entering the borehole. A lockable, protective casing was cemented in place over the protruding 

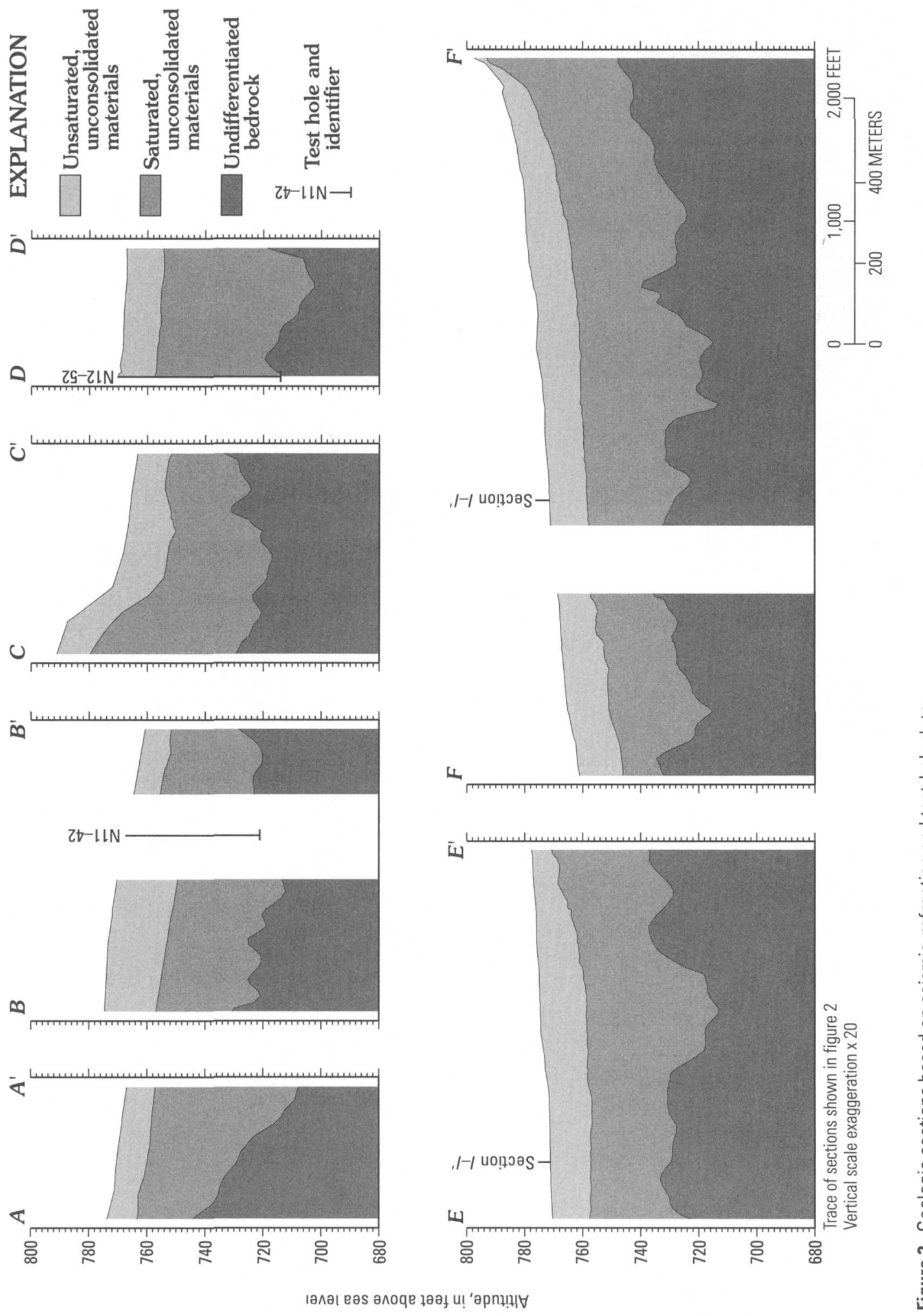

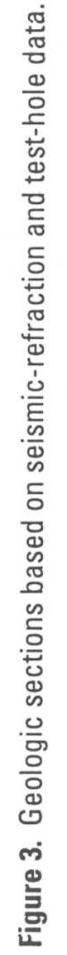



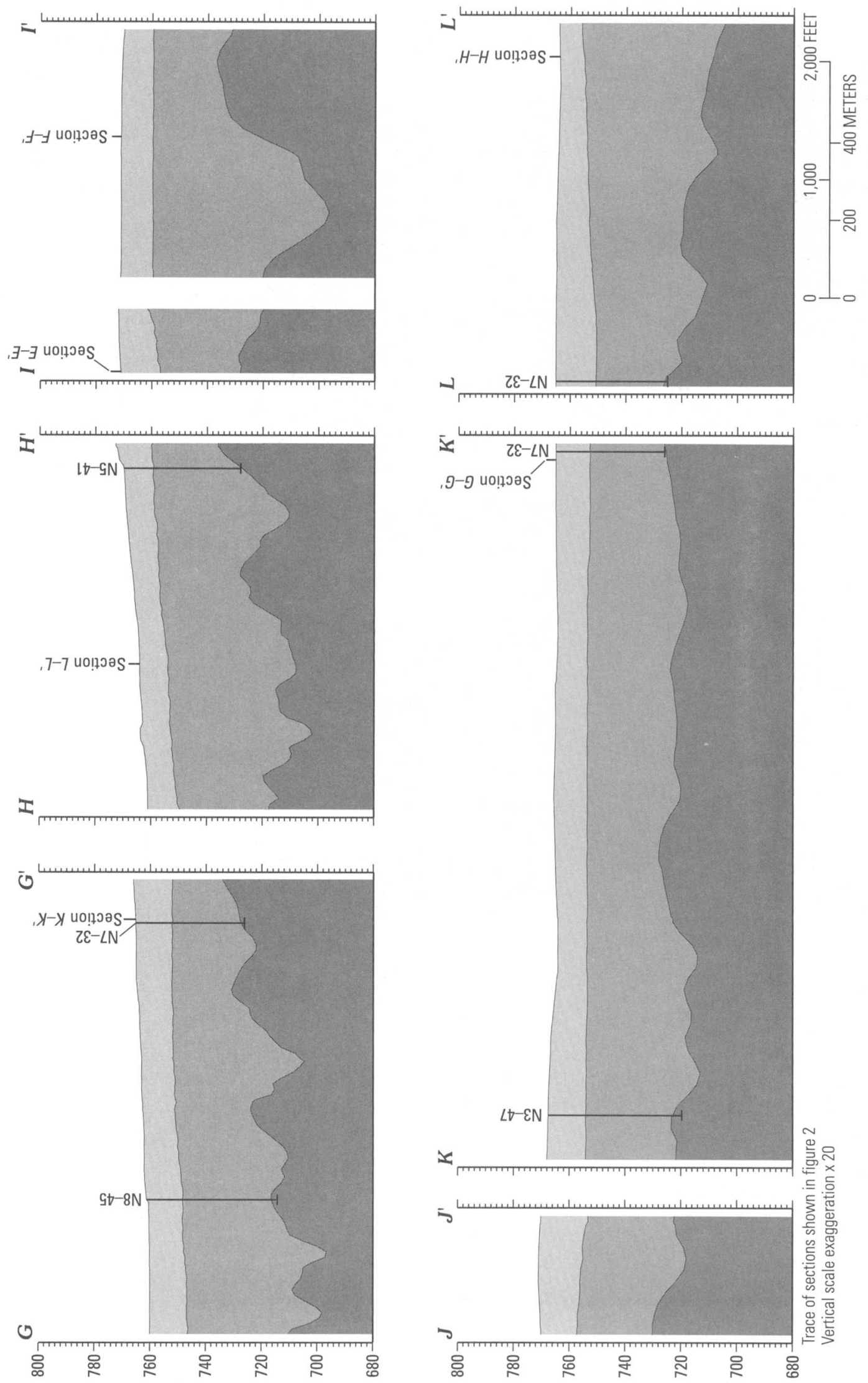

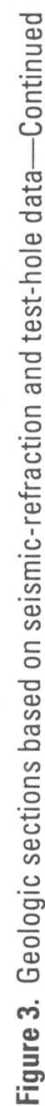


portion of the riser pipe. Wells were pumped after construction to develop the sand pack surrounding the screen.

Table 2 lists observation-well locations and associated geologic information. The prefix ' $N$ ' designates observation wells drilled by USGS personnel in 1999. Information about unconsolidated materials, including depth to bedrock and sand and gravel thickness, for test holes designated 'Layne' were obtained from Layne-Western Company, Inc. (written commun. to Newton Waterworks, 1980). Additional test-hole data were obtained from Northway Well and Pump Company (written commun. to Newton Waterworks, 1998) and are designated 'Northway'.

\section{Thickness and Lithology}

Descriptive logs of USGS, Layne-Western, and Northway test holes drilled in the study area (table 2) indicate shale, clay, glacial till, or limestone underlie the sand and gravel of the alluvial aquifer. Gray clay or glacial till can have the same appearance and drilling characteristics in the study area as a soft gray shale, and additional analysis would be required to determine the exact lithology of these deposits. For the purposes of this report, wells or test holes penetrating gray clay or glacial till beneath the sand and gravel are assumed to be shale and the top of the bedrock surface. On the basis of a limited number of wells and test holes that penetrate deeper into the bedrock, this gray shale or clay layer is from 0 to about $15 \mathrm{ft}$ thick and overlies a hard white limestone. Depths to bedrock in wells and test holes ranged from 34 to more than $60 \mathrm{ft}$. The greatest depths to bedrock occurred in the southeastern part of the well field area where a thicker layer of sand and gravel may be a terrace or dune deposit.

Seismic-refraction data can be used to identify boundaries between unsaturated and saturated unconsolidated materials and saturated unconsolidated materials and bedrock. Seismic-refraction data do not differentiate between the types of material comprising the unconsolidated material. Therefore, thicknesses of aquifer material are inferred from the total thickness of unconsolidated deposits within the South Skunk River Valley. Additional test drilling is needed to confirm the interpreted depth to bedrock in areas where test-hole data are not available and to determine the type of material composing the unconsolidated deposits.

Seismic-refraction data show variations in the depth to the bedrock surface in places in the study area (fig. 3). The removal of bedrock materials through erosion and weathering may explain local differences in depth to bedrock and type of material composing the bedrock surface seen in the descriptive logs of wells and test holes fully penetrating the alluvium. For example, the two Northway test holes listed in table 2 are about $1,300 \mathrm{ft}$ apart, yet the depth-to-bedrock varies by $9 \mathrm{ft}$. The type of material composing the bedrock surface in the two test holes also is dissimilar.

Figure 4 shows the altitude of the bedrock surface in feet above sea level in the study area. This map was prepared from depth-to-bedrock data from wells, test holes, and seismic-refraction shot-point locations. Figure 4 shows three areas in the study area where the bedrock surface is lower than $720 \mathrm{ft}$ above sea level - an area about 5,000 ft west of the present well field area, the present well field area, and an area about $5,000 \mathrm{ft}$ southeast of the present well field area.

The thickness of unconsolidated alluvial deposits is shown in figure 5. This map was created by a geographic information system (GIS) process. A grid of the altitude of the interpreted bedrock surface was created and subtracted from a grid of the land-surface altitude in the study area to provide a gridded estimate of the thickness of unconsolidated deposits. The greatest thicknesses of unconsolidated alluvial deposits, in excess of $60 \mathrm{ft}$, coincide with the areas of lowest bedrock-surface altitude. The altitude of the flood-plain land surface is relatively uniform, and the deeper bedrock-surface areas appear to be erosional channels in the bedrock that have been subsequently filled by unconsolidated deposits.

\section{Ground-Water Flow}

Water levels were measured in observation and municipal water-supply wells during February, June, and October 2000 with calibrated steel tapes or electric line. Altitudes of measuring points on the wells were surveyed to sea-level datum, and all water-level measurements were converted to altitudes above sea level. In addition, reference points surveyed to sea level were established on bridge crossings over the South Skunk River near the upstream and downstream extremes of the study area. River stages of the South Skunk River were measured to determine altitude and gradient of surface water in the study area at the time* of ground-water-level measurements. Static (nonpumping) water levels were measured in municipal wells. There was less than $10-\mathrm{ft}$ difference between water levels at different well locations. Water levels measured during this study are given in table 3 .

River stages in the South Skunk River were similar for each measurement date, and the gradient 
Table 2. Description of drilled test holes and geologic information

\begin{tabular}{|c|c|c|c|}
\hline $\begin{array}{l}\text { Test-hole } \\
\text { identifier } \\
\text { (fig. 2) }\end{array}$ & $\begin{array}{l}\text { Location land net }{ }^{2} \\
\text { (latitude, longitude) }\end{array}$ & Geologic unit & $\begin{array}{l}\text { Drillers log/cuttings description } \\
\text { (feet below land surface) }\end{array}$ \\
\hline N1-33 & $\begin{array}{l}\text { T20N-R79W-12DCDA } \\
\left(41^{\circ} 39^{\prime} 38.29^{\prime \prime}, 93^{\circ} 07^{\prime} 16.47^{\prime \prime}\right)\end{array}$ & Undifferentiated Paleozoic & $\begin{array}{l}\text { 0-6, Dark-brown silt, clayey } \\
6-12 \text {, Light-brown silt } \\
\text { 12-15, Light-brown sand, silty, fine } \\
\text { 15-23, Sand, fine } \\
\text { 23-32, Medium-brown sand, fine to medium, well } \\
\text { rounded } \\
32-33 \text {, Gray-brown sand, with large gravel } \\
\text { 33-34, Clay, glacial till, stiff } \\
\text { 34, Bedrock }\end{array}$ \\
\hline N3-47 & $\begin{array}{l}\text { T79N-R20W-13DBCC } \\
\left(41^{\circ} 38^{\prime} 55.69^{\prime \prime}, 93^{\circ} 07^{\prime} 32.01^{\prime \prime}\right)\end{array}$ & Quaternary-age alluvium & $\begin{array}{l}\text { 0-1, Lime, fill } \\
\text { 1-2, Dark-brown soil, silty, small pebbles } \\
\text { 2-3, Medium-brown soil, silty, fine sand } \\
\text { 3-9, Medium-brown silt, soft } \\
\text { 9-11, Gray silt, sandy, soft, damp } \\
\text { 11-12, Fine sand, oxidized } \\
\text { 12-18, Dark-brown sand, fine, wet at } 17 \text { feet } \\
\text { 18-20, Medium-brown sand, fine to medium, some silt } \\
20-24 \text {, Gray sand, fine to coarse } \\
24-44 \text {, Gray sand, fine to coarse, pea gravel } \\
44-47 \text {, Gravel } \\
47-48 \text {, Clay, glacial till, hard }\end{array}$ \\
\hline N4-51 & $\begin{array}{l}\text { T79N-R19W-18CBAB } \\
\left(41^{\circ} 39^{\prime} 06.57^{\prime \prime}, 93^{\circ} 06^{\prime} 44.28^{\prime \prime}\right)\end{array}$ & Quaternary-age alluvium & $\begin{array}{l}\text { 0-3, Dark-brown soil, silty } \\
\text { 3-4, Dark-brown silt, clayey } \\
\text { 4-5, Black silt, clayey } \\
\text { 5-9, Dark-brown silt, clayey } \\
\text { 9-10, Dark-brown sand, silty } \\
\text { 10-14, Brown sand, fine, some silt lenses } \\
\text { 14-22, Light-brown sand, fine } \\
\text { 22-51, Medium-brown sand, fine to medium, gravel at } \\
\text { 45 feet } \\
\text { 51, Clay, glacial till, hard }\end{array}$ \\
\hline N5-41 & $\begin{array}{l}\text { T79N-R19W-19ADAA } \\
\left(41^{\circ} 38^{\prime} 28.28^{\prime \prime}, 93^{\circ} 05^{\prime} 46.83^{\prime \prime}\right)\end{array}$ & Quaternary-age alluvium & $\begin{array}{l}\text { 0-4, Medium-brown sand, fine } \\
\text { 4-5, Dark-brown sand, silty, fine } \\
5-10 \text {, Dark-brown silt, sandy, stiff } \\
\text { 10-17, Medium-brown sand, silty, fine, dark brown at } \\
\text { 12-14 feet, wet at } 17-18 \text { feet } \\
\text { 17-25, Dark-brown sand, fine } \\
\text { 25-42, Medium-brown sand, fine to coarse } \\
\text { 42, Clay, glacial till }\end{array}$ \\
\hline N6-46 & $\begin{array}{l}\text { T79N-R19W-19DDDA } \\
\left(41^{\circ} 37^{\prime} 53.00^{\prime \prime}, 93^{\circ} 05^{\prime} 47.06^{\prime \prime}\right)\end{array}$ & Quaternary-age alluvium & $\begin{array}{l}0-4 \text {, Black soil, silty } \\
4-8 \text {, Dark-brown silt, clayey, stiff } \\
8-10 \text {, Medium-brown silt, clayey, some sand, damp at } \\
10 \text { feet } \\
\text { 10-12, Gray sand, clayey, silty } \\
\text { 12-20, No returns, soft at } 15 \text { feet } \\
20-40 \text {, Gray sand, fine, soupy } \\
40-45 \text {, Same as above only coarser, cleaner, fine to } \\
\text { pea-size gravel } \\
45-46 \text {, Gravel, large } \\
46-47 \text {, Clay, glacial till, stiff }\end{array}$ \\
\hline
\end{tabular}


Table 2. Description of drilled test holes and geologic information-Continued

\begin{tabular}{|c|c|c|}
\hline $\begin{array}{c}\text { Test-hole } \\
\text { identifier' } \\
\text { (fig. 2) }\end{array}$ & $\begin{array}{l}\text { Location land net }{ }^{2} \\
\text { (latitude, longitude) }\end{array}$ & $\begin{array}{l}\text { Drillers log/cuttings description } \\
\text { (feet below land surface) }\end{array}$ \\
\hline N7-32 & $\begin{array}{l}\text { T79N-R19W-19BADD } \\
\left(41^{\circ} 38^{\prime} 30.53^{\prime \prime}, 93^{\circ} 06^{\prime} 22.26^{\prime \prime}\right)\end{array}$ & $\begin{array}{l}\text { 0-1, Dark-brown soil, silty } \\
\text { 1-4, Dark-brown clay, silty } \\
\text { 4-6, Medium-brown silt, clayey, stiff from } 5-6 \text { feet } \\
\text { 6-7, Gray-brown silt, sandy } \\
\text { 7-8, Brown sand, fine } \\
\text { 8-12, Gray sand, silty } \\
\text { 12-20, No returns, very soft } \\
\text { 20-38, Gray sand, coarse } \\
38-39 \text {, Gravely } \\
39 \text {, Clay, glacial till, very hard }\end{array}$ \\
\hline N8-45 & $\begin{array}{l}\text { T79N-R19W-19CADD } \quad \text { Quaternary-age alluvium } \\
\left(41^{\circ} 38^{\prime} 02.34^{\prime \prime}, 93^{\circ} 06^{\prime} 21.55^{\prime \prime}\right)\end{array}$ & $\begin{array}{l}\text { 0-2, Dark-brown soil, silty } \\
\text { 2-4, Dark-brown silt } \\
\text { 4-5, Medium-brown silt, sandy } \\
\text { 5-6, Medium-brown sand, silty, fine } \\
\text { 6-12, Dark-brown sand, silty, fine } \\
\text { 12-30, Gray sand, fine to medium, small gravel at } 22 \text { feet, } \\
\text { wet } \\
\text { 30-46, Same as above, gravel lense at } 43 \text { feet, large } \\
\text { gravel lense at } 45 \text { feet } \\
46-47 \text {, Clay, glacial till, coal, very hard }\end{array}$ \\
\hline N9-45 & $\begin{array}{l}\text { T79N-R20W-11CDAD } \quad \text { Quaternary-age alluvium } \\
\left(41^{\circ} 39^{\prime} 40.24^{\prime \prime}, 93^{\circ} 08^{\prime} 46.28^{\prime \prime}\right)\end{array}$ & $\begin{array}{l}\text { 0-3, Soil and road fill } \\
\text { 3-6, Dark-brown silt, very stiff } \\
\text { 6-8, Medium-brown clay, silty, softer than above } \\
\text { 8-12, Medium-brown sand, silty, fine } \\
\text { 12-18, Medium-brown sand, fine, wet at } 15 \text { feet } \\
\text { 18-25, As above, coarser } \\
\text { 25-44, Gray-brown sand, fine to very coarse, soupy, some } \\
\text { pea gravel } \\
\text { 44-45, Gravel } \\
\text { 45-46, Clay, glacial till, very stiff }\end{array}$ \\
\hline $\mathrm{N} 10-45$ & $\begin{array}{l}\text { T79N-R20W-14CBDD } \quad \text { Quaternary-age alluvium } \\
\left(41^{\circ} 38^{\prime} 53.92^{\prime \prime}, 93^{\circ} 09^{\prime} 00.87^{\prime \prime}\right)\end{array}$ & $\begin{array}{l}\text { 0-2, Dark-brown soil, silty } \\
\text { 2-4, Medium-brown silt, clayey } \\
\text { 4-9, Medium-brown clay, silty, stiff } \\
\text { 9-15, Medium-brown silt, sandy, soft, no returns } \\
\text { 10-18 feet } \\
\text { 15-25, Medium-brown sand, fine } \\
\text { 25-35, Medium-brown sand, fine to coarse } \\
\text { 35-47, Medium-brown to gray sand, fine to very coarse } \\
\text { 47-48, Clay, glacial till, very hard }\end{array}$ \\
\hline N11-42 & $\begin{array}{l}\text { T79N-R20W-23AAAA } \quad \text { Quaternary-age alluvium } \\
\left(41^{\circ} 38^{\prime} 40.02^{\prime \prime}, 93^{\circ} 08^{\prime} 10.74^{\prime \prime}\right)\end{array}$ & $\begin{array}{l}\text { 0-3, Dark-brown soil, silty } \\
\text { 3-5, Dark-brown silt } \\
\text { 5-7, Dark-brown silt, clayey, very stiff } \\
\text { 7-14, No returns, soft } \\
\text { 14-25, Gray-brown sand, silty, fine, wet } \\
25-30 \text {, Gray-brown sand, some silt, fine to coarse } \\
\text { 30-42, Gray-brown sand, fine to coarse } \\
42-43 \text {, Gravel, very large } \\
43 \text {, Could not penetrate large gravel }\end{array}$ \\
\hline
\end{tabular}


Table 2. Description of drilled test holes and geologic information-Continued

\begin{tabular}{|c|c|c|c|}
\hline $\begin{array}{l}\text { Test-hole } \\
\text { identifier' } \\
\text { (fig. 2) }\end{array}$ & $\begin{array}{l}\text { Location land net }{ }^{2} \\
\text { (latitude, longitude) }\end{array}$ & Geologic unit & $\begin{array}{l}\text { Drillers log/cuttings description } \\
\text { (feet below land surface) }\end{array}$ \\
\hline N12-52 & $\begin{array}{l}\text { T79N-R20W-25AAAA } \\
\left(41^{\circ} 37^{\prime} 48.54^{\prime \prime}, 93^{\circ} 06^{\prime} 58.84^{\prime \prime}\right)\end{array}$ & Quaternary-age alluvium & $\begin{array}{l}\text { 0-2, Medium-brown silt } \\
\text { 2-4, Dark-brown silt } \\
\text { 4-5, Dark-brown silt, clayey, stiff } \\
\text { 5-7, Medium-brown silt, clayey, stiff } \\
\text { 7-8, Medium-brown clay, silty, softer } \\
\text { 8-9, No returns } \\
\text { 9-10, Sand and clay, oxidized } \\
\text { 10-11, Medium-brown silt, sandy } \\
\text { 11-13, No returns } \\
\text { 13-14, Sand, fine, oxidized, wet } \\
\text { 14-20, Medium-brown sand, silty, fine } \\
\text { 20-25, As above, fine to medium } \\
\text { 25-48, As above, fine to very coarse, little silt, some pea } \\
\quad \text { gravel } \\
\text { 48-51, Gravel } \\
\text { 51-55, Gray sand, coarse } \\
\text { 55-56, Gravel, very coarse } \\
\text { 56, Clay, glacial till, stiff }\end{array}$ \\
\hline$N 13-41$ & $\begin{array}{l}\text { T79N-R19W-30ADDD } \\
\left(41^{\circ} 37^{\prime} 22.91^{\prime \prime}, 93^{\circ} 05^{\prime} 47.02^{\prime \prime}\right)\end{array}$ & Quaternary-age alluvium & $\begin{array}{l}\text { 0-1, Dark-brown soil, silty } \\
\text { 1-2, Dark-brown silt, stiff } \\
2-4 \text {, Medium-brown silt, stiff } \\
\text { 4-6, Medium-brown silt, clayey } \\
6-9 \text {, Medium-brown clay, silty, very soft } \\
\text { 9-14, No returns, soft } \\
\text { 14-20, Medium-brown sand, silty, fine to medium } \\
20-25 \text {, Gray-brown sand, fine to medium } \\
25-30 \text {, Gray sand, fine to medium } \\
30-40 \text {, Gray-brown sand, fine to mostly coarse } \\
40-44 \text {, As above, fine sand to pea gravel, mostly very } \\
\text { coarse sand } \\
44-45 \text {, Gravel, very large, unable to penetrate gravel }\end{array}$ \\
\hline $\begin{array}{l}\text { Northway } \\
\text { R-98-01 }\end{array}$ & $\begin{array}{l}\text { T79N-R19W-18CBAB } \\
\left(41^{\circ} 39^{\prime} 04.50^{\prime \prime}, 93^{\circ} 06^{\prime} 49.27^{\prime \prime}\right)\end{array}$ & $\begin{array}{l}\text { Quaternary-age alluvium } \\
\text { Undifferentiated Paleozoic }\end{array}$ & $\begin{array}{l}0-26, \text { Clay, sandy } \\
26-42 \text {, Sand, fine to medium, and gravel } \\
42-53 \text {, Sand, fine to coarse, and gravel } \\
53-60 \text {, Shale, gray }\end{array}$ \\
\hline $\begin{array}{l}\text { Northway } \\
\text { R-98-02 }\end{array}$ & $\begin{array}{l}\text { T79N-R19W-18CDBB } \\
\left(41^{\circ} 38^{\prime} 51.98^{\prime \prime}, 93^{\circ} 06^{\prime} 42.59^{\prime \prime}\right)\end{array}$ & $\begin{array}{l}\text { Quaternary-age alluvium } \\
\text { Undifferentiated Paleozoic }\end{array}$ & $\begin{array}{l}0-4 \text {, Top soil } \\
4-12 \text {, Sand, fine } \\
\text { 12-44, Sand, fine to coarse, and gravel } \\
44-50 \text {, Limestone, with gray shale streaks }\end{array}$ \\
\hline Layne TH1 & T79N-R20W-13CDAB & Quaternary-age alluvium & $\begin{array}{l}0-4 \text {, Top soil, black } \\
4-9 \text {, Clay, dark brown, gumbo } \\
9-10 \text {, Sand, brown, silty } \\
\text { 10-16.5, Sand, dark grayish white, black river mud and } \\
\text { some wood cuttings } \\
\text { 16.5-20, Sand and gravel, fine to medium, grayish white } \\
20-25 \text {, Sand and gravel, test holes to coarse dark grayish } \\
\text { white } \\
25-30 \text {, Sand and gravel, fine to medium, grayish white } \\
30-35 \text {, Sand and gravel, fine to medium, grayish white, } \\
\text { cobble at } 34 \text { feet } \\
35-40 \text {, Sand and gravel, medium to coarse, grayish white, } \\
\text { with cobbles } \\
40-42 \text {, Sand and gravel, grayish white, with cobbles } \\
42 \text {, Limestone, soft }\end{array}$ \\
\hline
\end{tabular}


Table 2. Description of drilled test holes and geologic information-Continued

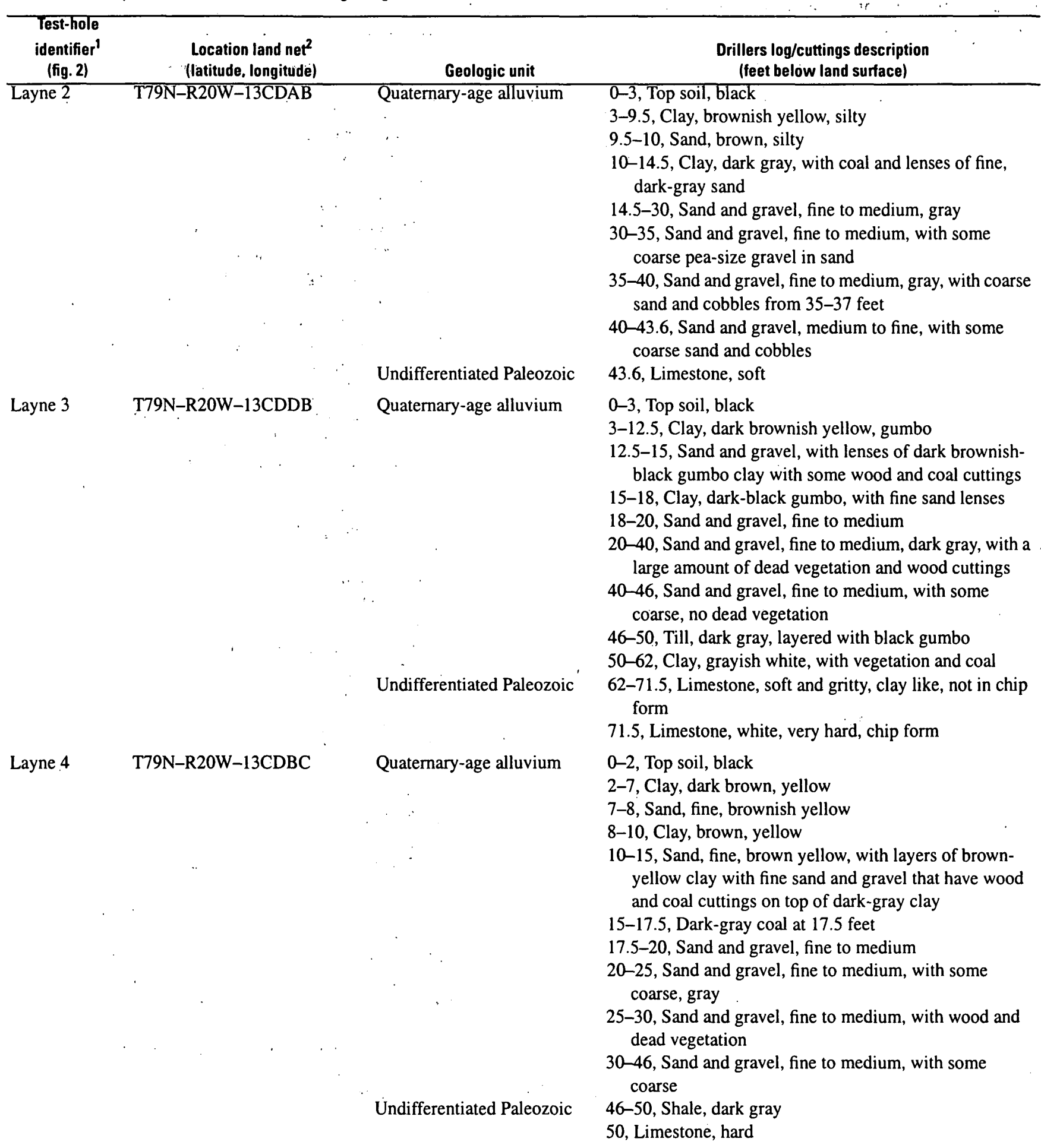


Table 2. Description of drilled test holes and geologic information-Continued

\begin{tabular}{|c|c|c|c|}
\hline $\begin{array}{c}\text { Test-hole } \\
\text { identifier } \\
\text { (fig. 2) }\end{array}$ & $\begin{array}{l}\text { Location land net }{ }^{2} \\
\text { (latitude, longitude) }\end{array}$ & Geologic unit & $\begin{array}{l}\text { Drillers log/cuttings description } \\
\text { (feet below land surface) }\end{array}$ \\
\hline Layne 5 & T79N-R20W-13DBCC & Quaternary-age alluvium & $\begin{array}{l}\text { 0-2, Top soil, black } \\
\text { 2-5, Black river gumbo } \\
5-9 \text {, Black river gumbo } \\
\text { 9-10, Clay, yellow, brown } \\
\text { 10-15, Sand and gravel, fine to medium } \\
\text { 15-20, Sand and gravel, fine to medium, with some } \\
\text { coarse grayish dark sand } \\
\text { 20-25, Sand and gravel, fine to medium, gray } \\
\text { 25-30, Sand and gravel, fine to medium, gray, with good } \\
\text { size pea gravel within } \\
\text { 30-35, Sand and gravel, fine to medium, with some } \\
\text { coarse, cobbles at } 33 \text { feet } \\
35-40, \text { Sand and gravel, fine to medium, very clean } \\
40-43, \text { Sand, medium to coarse, brownish white } \\
43-58 \text {, Shale, gray, with grayish-brown till on top of } \\
\text { shale, shale turns to light gray to white } \\
\text { 58-69, Shale, white, with particles of grit that turns to } \\
\text { chips of limestone } \\
69 \text {, Limestone, hard }\end{array}$ \\
\hline Layne $10-80$ & T79N-R19W-18CBDB & $\begin{array}{l}\text { Quatemary-age alluvium } \\
\text { Undifferentiated Paleozoic }\end{array}$ & $\begin{array}{l}0-5, \text { Sand, fine } \\
5-12 \text {, Sand, fine, clay } \\
12-17 \text {, Clay, brown } \\
17-25 \text {, Sand, fine to coarse, buff color } \\
25-66 \text {, Sand and gravel, coarse } \\
66-73 \text {, Shale, blue } \\
73-75, \text { Limestone, shaly }\end{array}$ \\
\hline Layne 11 & T79N-R19W-18BCCD & Quaternary-age alluvium & $\begin{array}{l}\text { 0-13, Sand, very fine, yellowish brown } \\
\text { 13-15, Clay, yellow } \\
\text { 15-20, Sand, very fine, yellow brown, with lenses of } \\
\text { yellow clay } \\
20-23 \text {, Sand, very fine, yellow brown } \\
23-25 \text {, Sand, fine, brown } \\
25-30 \text {, Sand and gravel, fine to medium, with some } \\
\text { coarse } \\
\text { 30-35, Sand and gravel, medium to coarse, turns to fine } \\
\text { sand at } 31.5 \text { feet } \\
35-40, \text { Sand and gravel, fine to medium, brown } \\
40-45 \text {, Sand and gravel, fine, with some medium, brown } \\
45-55 \text {, Sand and gravel, fine, with some medium, } \\
\text { brownish white } \\
55-59, \text { Sand and gravel, fine to medium, with some } \\
\text { coarse, brown } \\
59 \text {, Limestone, grayish white, hard }\end{array}$ \\
\hline
\end{tabular}


Table 2. Description of drilled test holes and geologic information-Continued

\begin{tabular}{ccc}
\hline $\begin{array}{c}\text { Test-hole } \\
\text { identifier' } \\
\text { (fig. 2) }\end{array}$ & $\begin{array}{c}\text { Location land net } \\
{ }^{2}\end{array}$ & (latitude, longitude) \\
\hline Layne 12 & T79N-R20W-13DBBA & Quatemary-age alluvium
\end{tabular}

5-8, Gumbo, yellowish black

8-10, Clay, yellow

10-11.5, Clay, yellow, with lenses of fine sand

11.5-15, Sand and gravel, fine to medium, brown

$15-20$, Sand and gravel, fine to medium, brown

$20-25$, Sand and gravel, fine to medium, with wood and dead vegetation from 23-25 feet

25-30, Sand and gravel, mostly fine to medium, gray, wood stops at 26 feet 7 inches

$30-35$, Sand and gravel, medium to coarse, with some fine cobbles at 32-35 feet

$35-37$, Sand and gravel, mostly fine to medium

$37-43$, Sand and gravel, fine, with some medium, grayish white

43-45.5, Sand and small cobbles, fine, grayish white 45.5-55, Till, blue gray

Layne 13

T79N-R20W-13DBAA

Quaternary-age alluvium

Undifferentiated Paleozoic

Layne 14

T79N-R19W-18CDBB

Quaternary-age alluvium
$0-2$, Top soil, black

$2-4$, Gumbo, black

4-7, Gumbo, yellow

7-9, Clay, yellow

9-10, Sand, rusty brown

10-15, Sand and gravel, fine, gray

15-20, Sand and gravel, fine to medium, gray

20-25, Sand and gravel, fine, with some medium, dead vegetation from $23-24.5$ feet

25-30, Sand and gravel, fine to medium, with some coarse, gray

$30-35$, Sand and gravel, fine to medium, with some coarse cobbles from 32-34.5 feet

$35-40$, Sand and gravel, medium to coarse, with some fine cobbles from $36-40$ feet, mixed

40-43.75, Sand and gravel, medium to coarse, with cobbles, gray

43.75-44, Limestone, light yellow, very hard

$0-5$, Sand, very fine, brown

5-8, Till, brown

$8-10$, Till, brownish gray

10-13.4, Clay, brownish gray, silty

13.4-16, Sand, very fine, brownish gray

$16-20$, Sand and gravel, fine to medium, brownish gray

20-30, Sand and gravel, fine to medium, brown

$30-35$, Sand and gravel, medium to coarse, with some fine cobbles at 32-34 feet

35-38, Sand and gravel, fine, white

$38-40$, Sand and gravel, fine to medium, brown

$40-45$, Sand and gravel, fine to medium, with some coarse

45-49, Sand and gravel, medium to coarse, with small boulders and large cobbles

49-55, Clay, blue 
Table 2. Description of drilled test holes and geologic information-Continued

\begin{tabular}{|c|c|c|c|}
\hline $\begin{array}{l}\text { Test-hole } \\
\text { identifier' } \\
\text { (fig. 2) }\end{array}$ & $\begin{array}{l}\text { Location land net }{ }^{2} \\
\text { (latitude, longitude) }\end{array}$ & Geologic unit & $\begin{array}{l}\text { Drillers log/cuttings description } \\
\text { (feet below land surface) }\end{array}$ \\
\hline Layne 15 & T79N-R19W-18CDBB & Quaternary-age alluvium & $\begin{array}{l}0-2.5 \text {, Sand, very fine, brown } \\
2.5-5 \text {, Clay, brown } \\
5-8.7 \text {, Clay, brownish gray } \\
8.7-11 \text {, Clay, brown, silty } \\
\text { 11-14, Clay, rusty brownish yellow, turning into very fine } \\
\text { brownish-yellow sand } \\
\text { 14-15, Sand, fine, grayish yellow } \\
\text { 15-20, Sand and gravel, fine to medium, gray } \\
20-25 \text {, Sand and gravel, fine, with some medium, grayish } \\
\text { white } \\
25-30, \text { Sand and gravel, fine, with some medium, grayish } \\
\text { white } \\
30-35 \text {, Sand and gravel, fine to medium, gravel becoming } \\
\text { coarser } \\
35-40, \text { Sand and gravel, medium to coarse, with pea } \\
\text { gravel and cobbles at } 36-40 \text { feet } \\
40-45 \text {, Sand and gravel, medium to coarse, without pea } \\
\text { gravel } \\
45-50, \text { Sand and gravel, medium to coarse, with pea } \\
\text { gravel and cobbles within } \\
50-53.3 \text {, Sand and gravel, medium to coarse, with some } \\
\text { fine } \\
53.3 \text {, Limestone, white, very hard }\end{array}$ \\
\hline Layne 16 & $\begin{array}{l}\text { T79N-R19W-18CCAB } \\
\therefore\end{array}$ & Undifferentiated Paleozoic & $\begin{array}{l}0-2.5 \text {, Top soil, black, sandy } \\
2.5-5 \text {, Gumbo, black } \\
5-10 \text {, Clay, blackish gray yellow } \\
\text { 10-13, Clay, yellowish gray, silty } \\
\text { 13-15, Sand and gravel, fine, brown } \\
\text { 15-20, Sand and gravel, fine to medium, with some } \\
\text { coarse } \\
20-25 \text {, Sand and gravel, fine to medium, brown } \\
25-30, \text { Sand and gravel, fine to medium, with some } \\
\text { coarse, brown } \\
30-35 \text {, Sand and gravel, medium to coarse, with some } \\
\text { fine, brown } \\
35-40, \text { Sand and gravel, fine, brownish white } \\
40-45, \text { Sand and gravel, very fine, white } \\
45-50, \text { Sand and gravel, fine, with some medium, } \\
\text { brownish white } \\
50-54, \text { Sand and gravel, fine to medium, brown } \\
54 \text {, Limestone, very hard }\end{array}$ \\
\hline Layne 6-80 & T79N-R19W-19BBCD & Undifferentiated Paleozoic & $\begin{array}{l}0-5 \text {, Soil, black } \\
5-7 \text {, Clay, sandy } \\
7-12 \text {, Sand, fine to coarse } \\
\text { 12-13, Wood log } \\
\text { 13-32, Sand and gravel, coarse, blue and white } \\
32-44 \text {, Gravel and coarse sand, some fine } \\
44-45 \text {, Boulders and gravel } \\
45-46 \text {, Gravel and clay } \\
46-59.5 \text {, Shale, gray } \\
59.5-60 \text {, Limestone, shaley }\end{array}$ \\
\hline
\end{tabular}


Table 2. Description of drilled test holes and geologic information-Continued

\begin{tabular}{|c|c|c|c|c|}
\hline $\begin{array}{l}\text { Test-hole } \\
\text { identifier' } \\
\text { (fig. 2) }\end{array}$ & $\begin{array}{l}\text { Location land net } \\
\text { (latitude, longitude) }\end{array}$ & Geologic unit & $\begin{array}{l}\text { Drillers log/cuttings description } \\
\text { (feet below land surface) }\end{array}$ & . \\
\hline Layne 7-80 & T79N-R19W-19BBDC & Undifferentiated Paleozoic & $\begin{array}{l}\text { 0-7, Soil, black } \\
\text { 7-8, Sand, fine } \\
8-12 \text {, Clay, brown } \\
\text { 12-16, Sand, coarse, blue and white } \\
\text { 16-17, Clay, blue } \\
\text { 17-37, Sand and gravel, coarse, blue and white } \\
\text { 37-44, Sand, fine to coarse } \\
44-47 \text {, Gravel and boulders } \\
47-55 \text {, Shale, gray } \\
55-62 \text {, Limestone, gray, shaley }\end{array}$ & \\
\hline Layne 8-80 & T79N-R19W-18CCDA & $\begin{array}{l}\text { Quaternary-age alluvium } \\
\text { Undifferentiated Paleozoic }\end{array}$ & $\begin{array}{l}0-5 \text {, Soil, black } \\
5-15 \text {, Clay, blue gray } \\
15-27 \text {, Sand and gravel, coarse, blue and white } \\
27-44 \text {, Sand, fine to coarse } \\
44-46 \text {, Gravel and boulders } \\
46-47 \text {, Shale, gray } \\
47-54 \text {, Sandstone } \\
54-57 \text {, Shale, gray } \\
57, \text { Limestone }\end{array}$ & \\
\hline Layne 9-80 & $\begin{array}{c}\text { T79N-R19W-18CCAB } \\
\cdots\end{array}$ & $\begin{array}{l}\text { Quaternary-age alluvium } \\
\text { Undifferentiated Paleozoic }\end{array}$ & $\begin{array}{l}0-12 \text {, Sand, fine to coarse } \\
12-14 \text {, Clay, brown, sandy } \\
14-28 \text {, Sand and gravel, coarse } \\
28-40 \text {, Sand and gravel, coarse, some fine } \\
40-58.5 \text {, Sand and gravel, coarse, some pebbles } \\
58.5-62 \text {, Shale, blue black and gray }\end{array}$ & \\
\hline
\end{tabular}

\footnotetext{
${ }^{1}$ Sites N1-33 to N13-41 drilled by U.S. Geological Survey; November 3-11, 1999.

${ }^{2}$ Location indicated by township (north), range (west), and section. The letters after the section number represent successiveness subdivisions of the section assigned in a counterclockwise direction beginning with ' $\mathrm{A}$ ' in the northeast quarter. The first letter indicates a 160-acre area. Each successive letter indicates an area one-fourth the size of the area represented by the previous letter.
}

between bridge measuring points was consistently $0.44 \mathrm{ft}$ per $1,000 \mathrm{ft}$ of river channel.

Ground-water levels were higher during the June 2000 measurement than either the February or October 2000 measurements at all observation wells except wells N1-33 and N4-51 (fig. 2), which are closest to the municipal well field. The highest waterlevel altitude occurred at well N10-45 in the west, upgradient part of the study area. The lowest waterlevel altitudes were measured at observation well N4-51, which is east and downgradient from the well field (fig. 2).

A potentiometric-surface map of water levels in the alluvial aquifer for the June 2000 measurements is shown in figure 6 . Water levels are lowest in the well field area. Ground water flows radially towards the well field from adjacent areas of the alluvial aquifer. On the well-field side of the South Skunk River, water levels in the river are higher than adjacent groundwater levels except in the southeast corner of the study area, indicating flow from the river toward the well field. Gradients between the river and the well field were similar on the other measurement dates as well.

\section{Water Quality}

Samples were collected from the observation wells and the South Skunk River at Highway 14 on June 6-8, 2000 (table 4). Samples were analyzed for dissolved oxygen, $\mathrm{pH}$, specific conductance, temperature, and alkalinity onsite at the time of sample collection. Laboratory analyses consisted of common ions, nutrients, dissolved solids, bromide, iron, and manganese. Analyses were performed at the USGS National Water Quality Laboratory in Denver, Colorado.

Concentrations of specific conductance, alkalinity, calcium, magnesium, sodium, bicarbonate, fluoride, silica, dissolved solids, and bromide were similar for 


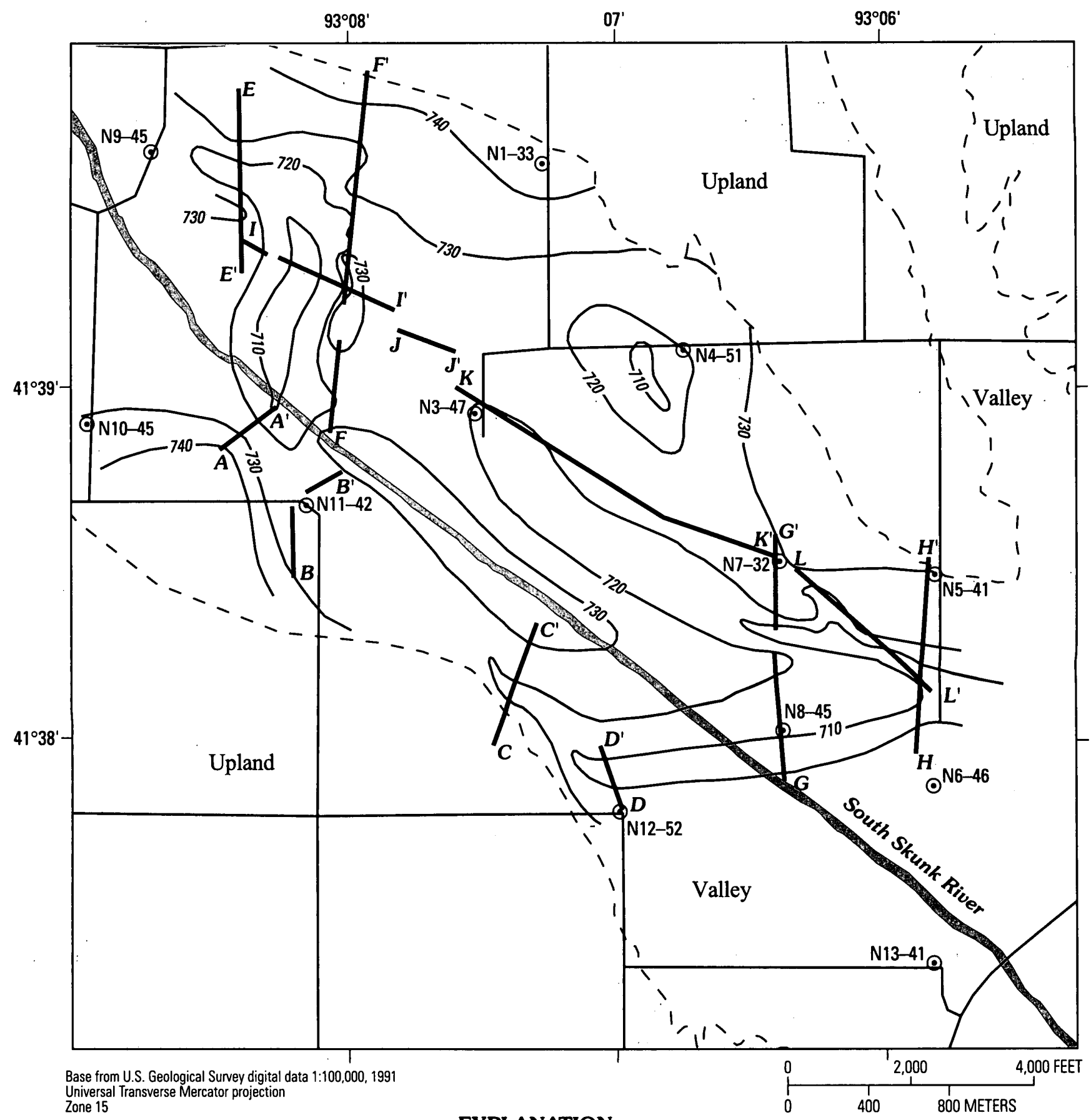

EXPLANATION

- 710 - Bedrock contour-Shows altitude of bedrock surface. Contour interval 10 feet. Datum is sea level

$A \quad A^{\prime}$ Trace of seismic geophysical section $A-A^{\prime}$ through $L-L^{\prime}$

- - Boundary between upland area and river valley

N7-32O Observation well and identifier

Figure 4. Altitude and configuration of bedrock surface based on seismic-retraction and test-hole data, South Skunk River Valley near Newton, lowa. 


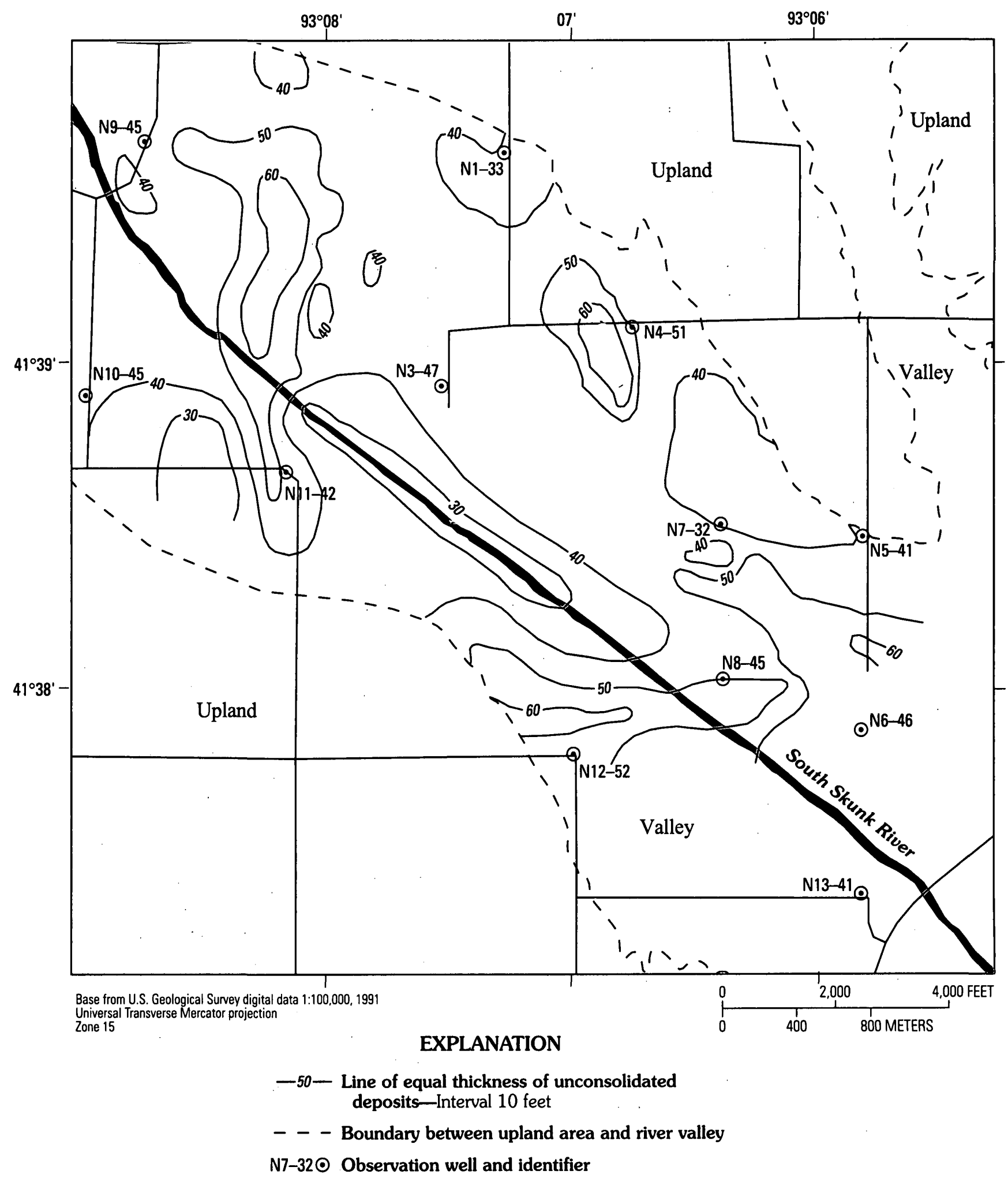

Figure 5. Thickness of unconsolidated deposits based on seismic-refraction and test-hole data, South Skunk River Valley near Newton, lowa. 
Table 3. Static water-level measurements from observation wells, - municipal wells, and surface-water sites in the South Skunk River alluvium near Newton, lowa, February, June, and October 2000

[Water levels in feet above sea level; observation wells measured February 29, June 7, and October 15; municipal wells measured February 27, June 7, and October 15; South Skunk River measured March 1, June 8, and October 17]

\begin{tabular}{|c|c|c|c|}
\hline $\begin{array}{l}\text { Data-collection } \\
\text { site (fig. 2) }\end{array}$ & February & June & October \\
\hline \multicolumn{4}{|c|}{ Observation wells } \\
\hline N1-33 & 757.02 & 756.34 & 754.57 \\
\hline N3-47 & 755.58 & 756.35 & 752.55 \\
\hline N4-51 & 741.41 & 740.60 & 736.66 \\
\hline N5-41 & 753.50 & 757.74 & 750.56 \\
\hline N6-46 & 756.47 & 759.48 & 752.33 \\
\hline N7-32 & 754.79 & 757.25 & 752.13 \\
\hline N8-45 & 753.70 & 755.09 & 751.23 \\
\hline N9-45 & 758.67 & 760.21 & 755.25 \\
\hline $\mathrm{N} 10-45$ & 764.21 & 769.91 & 761.41 \\
\hline N11-42 & 760.59 & 763.78 & 757.02 \\
\hline $\mathrm{N} 12-52$ & 757.85 & 760.03 & 754.96 \\
\hline N13-41 & 757.83 & 758.96 & 753.71 \\
\hline \multicolumn{4}{|c|}{ Municipal wells } \\
\hline Well 1 & 742.46 & 741.21 & 741.71 \\
\hline Well 3 & 745.04 & 742.13 & 743.04 \\
\hline Well 5 & 742.96 & 743.13 & 741.88 \\
\hline Well 6 & 743.91 & 742.16 & 741.49 \\
\hline Well 7 & 742.05 & 746.55 & 745.38 \\
\hline Well 8 & 742.02 & 739.77 & 739.02 \\
\hline Well 9 & 741.13 & 740.13 & 739.55 \\
\hline Well 10 & 742.35 & 740.35 & 739.43 \\
\hline Well 11 & 741.38 & 740.38 & 739.38 \\
\hline Well 12 & 739.12 & 737.79 & 738.20 \\
\hline Well 13 & 738.74 & 737.74 & 737.99 \\
\hline Well 14 & 741.89 & 743.39 & 743.72 \\
\hline Well 15 & 739.95 & 738.79 & 739.04 \\
\hline Well 16 & 739.85 & 738.43 & 738.85 \\
\hline Well 17 & 741.21 & 739.46 & 740.71 \\
\hline Well 18 & 740.44 & 737.61 & 738.77 \\
\hline Well 19 & 742.06 & 741.06 & 741.31 \\
\hline Well 20 & 741.35 & 739.60 & 740.18 \\
\hline Well 21 & 745.20 & 738.70 & 742.62 \\
\hline Well 22 & 740.21 & 738.71 & 739.96 \\
\hline Well 23 & 741.32 & 739.32 & 740.15 \\
\hline \multicolumn{4}{|c|}{ South Skunk River } \\
\hline $\begin{array}{l}\text { Neptune Street } \\
\text { bridge }\end{array}$ & 762.22 & 762.44 & 761.33 \\
\hline Highway 14 bridge & 753.74 & 754.00 & 752.84 \\
\hline
\end{tabular}

all samples. Samples from all observation wells except well N1-33 had low concentrations of dissolved oxygen.

Measured values of $\mathrm{pH}$, temperature, potassium, chloride, nitrite nitrogen, total phosphorus, and orthophosphorus were similar for all ground-water samples but higher for the river sample. River water was substantially more alkaline than ground-water samples. River water contained about twice as much potassium and chloride as ground-water samples. Ground-water samples typically contained ammonia plus organic nitrogen near or less than the method detection limit $(0.10 \mathrm{mg} / \mathrm{L})$, whereas the river-water sample was substantially higher $(0.30 \mathrm{mg} / \mathrm{L})$. River water also contained detectable concentrations of nitrite nitrogen, total phosphorus, and orthophosphorus, whereas ground-water samples were near or less than method detection limits.

Sulfate, ammonia nitrogen, nitrite plus nitrate, iron, and managanese concentrations varied. Sulfate was present in all samples, ranging from 34 to $112 \mathrm{mg} / \mathrm{L}$. River water contained sulfate concentrations similar to ground water in some observation wells. Ammonia nitrogen was detected in all samples, including the river-water sample, with the exception of two ground-water samples. Nitrite plus nitrate nitrogen was detected only in three ground-water samples and one river-water sample. Considering that groundwater samples contained no detectable nitrite concentrations, nitrite plus nitrate concentrations are composed primarily of nitrate nitrogen. One sample (well N1-33) exceeded the U.S. Environmental Protection Agency Maximum Contaminant Level for nitrate $(10 \mathrm{mg} / \mathrm{L}$ as $\mathrm{N})$ (U.S. Environmental Protection Agency, 1996). Iron concentrations ranged from.less than 10 to $2,350 \mu \mathrm{g} / \mathrm{L}$. Samples that were high in iron also were high in manganese. Samples that had iron concentrations less than the method detection limit were the same samples that had detectable nitrate nitrogen concentrations, indicating oxygenated conditions.

Results of the water-quality sampling indicate that reducing conditions are present at most of the alluvial ground-water sampling sites in the study area. Conditions that are indicative of a reducing environment are low dissolved oxygen, large concentrations of iron and managanese, nitrogen in the reduced forms of nitrite or ammonia, and potentially high sulfate concentrations. Samples that contained substantial amounts of dissolved oxygen contained low concentrations of iron 


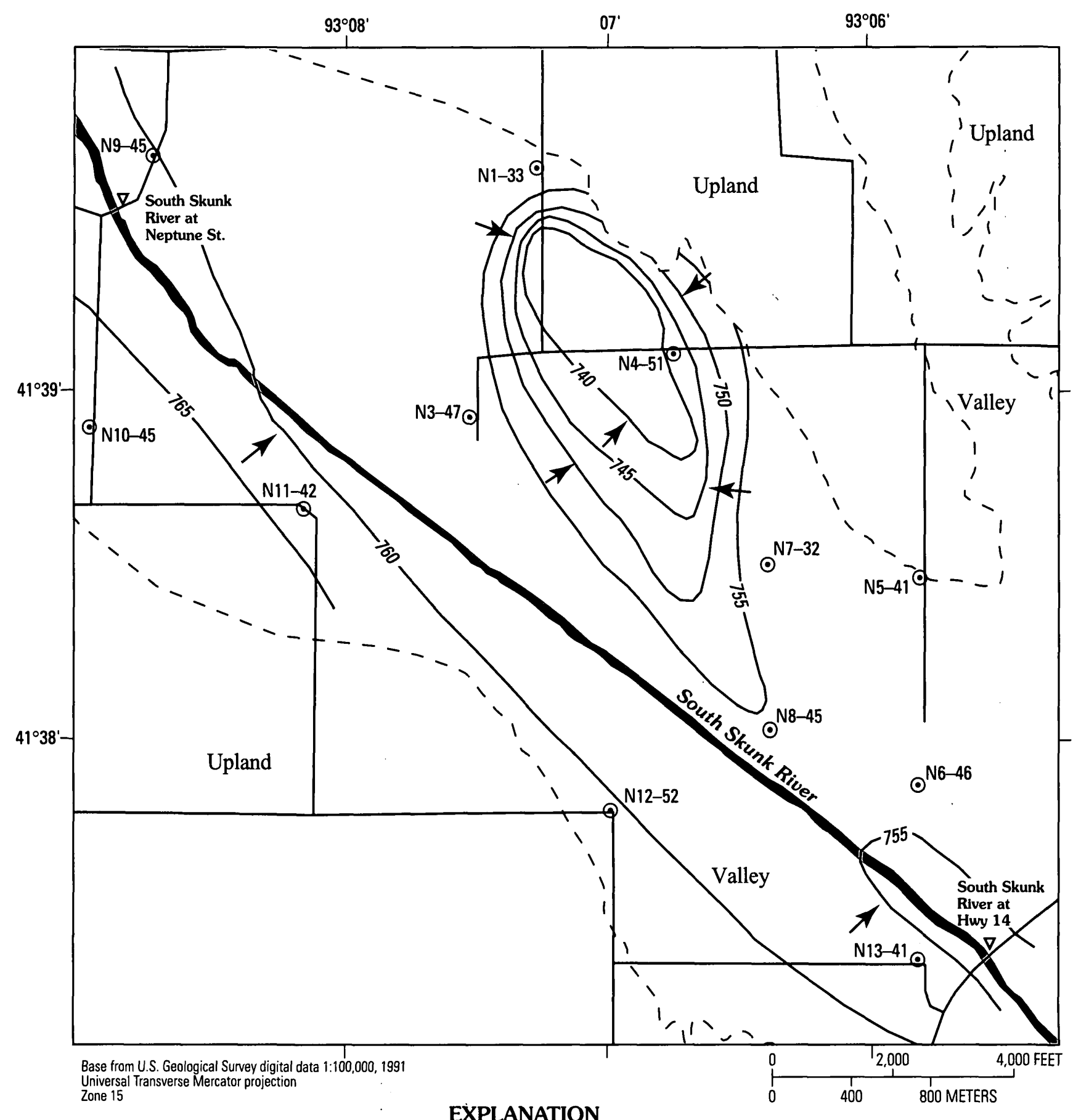

$$
\begin{aligned}
& \text { 755- Potentiometric contour-Shows altitude at which water } \\
& \text { level would have stood in tightly cased wells. Contour } \\
& \text { interval } 5 \text { feet. Datum is sea level } \\
& \longrightarrow \text { Approximate direction of ground-water flow } \\
& - \text { - Boundary between upland area and river valley }
\end{aligned}
$$

N7-32 $\odot$ Observation well and identifier

South Skunk
River at Hwy 14

Figure 6. Potentiometric surface of alluvial aquifer, South Skunk River Valley near Newton, lowa, June 6, 2000. 


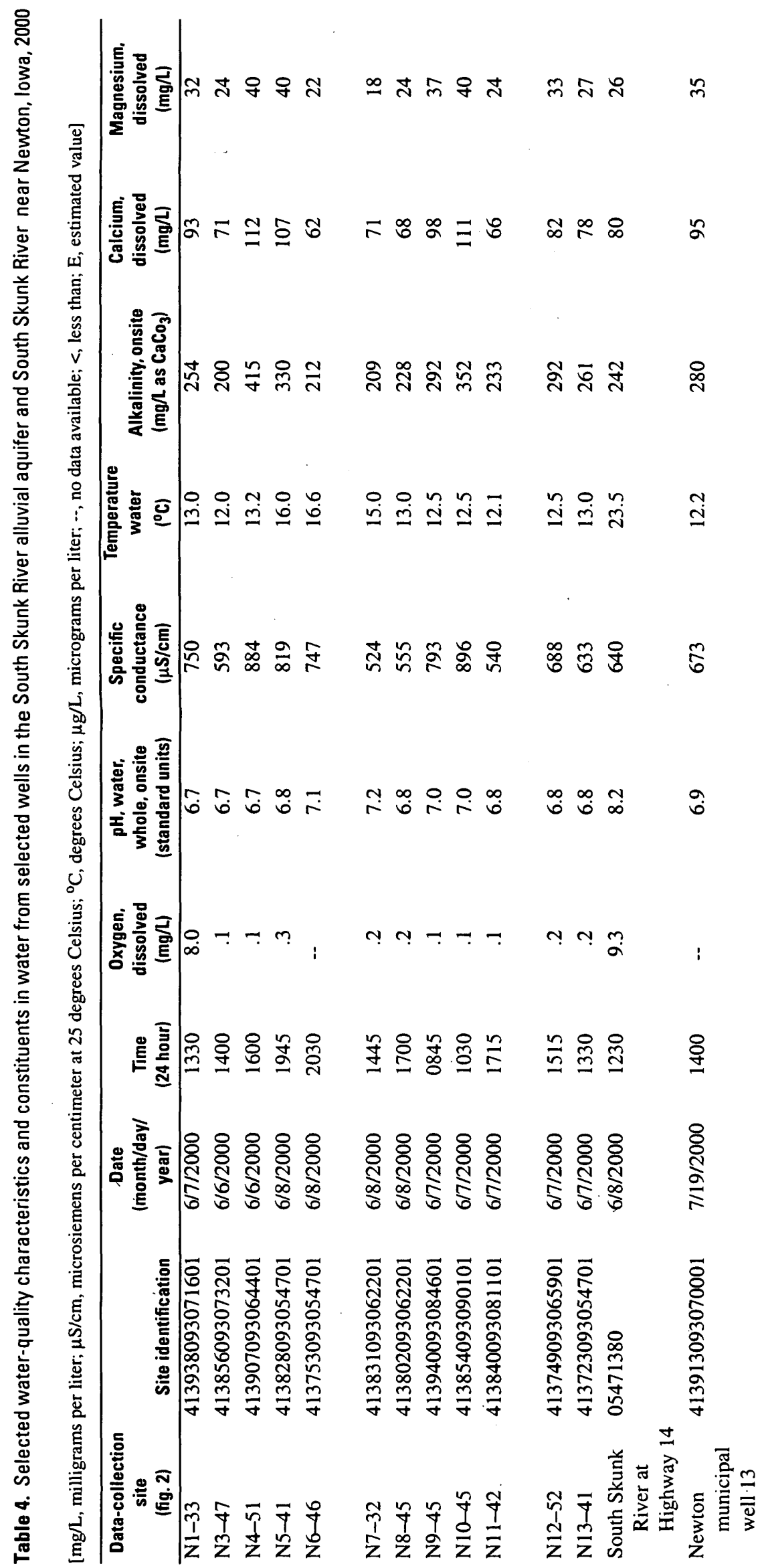




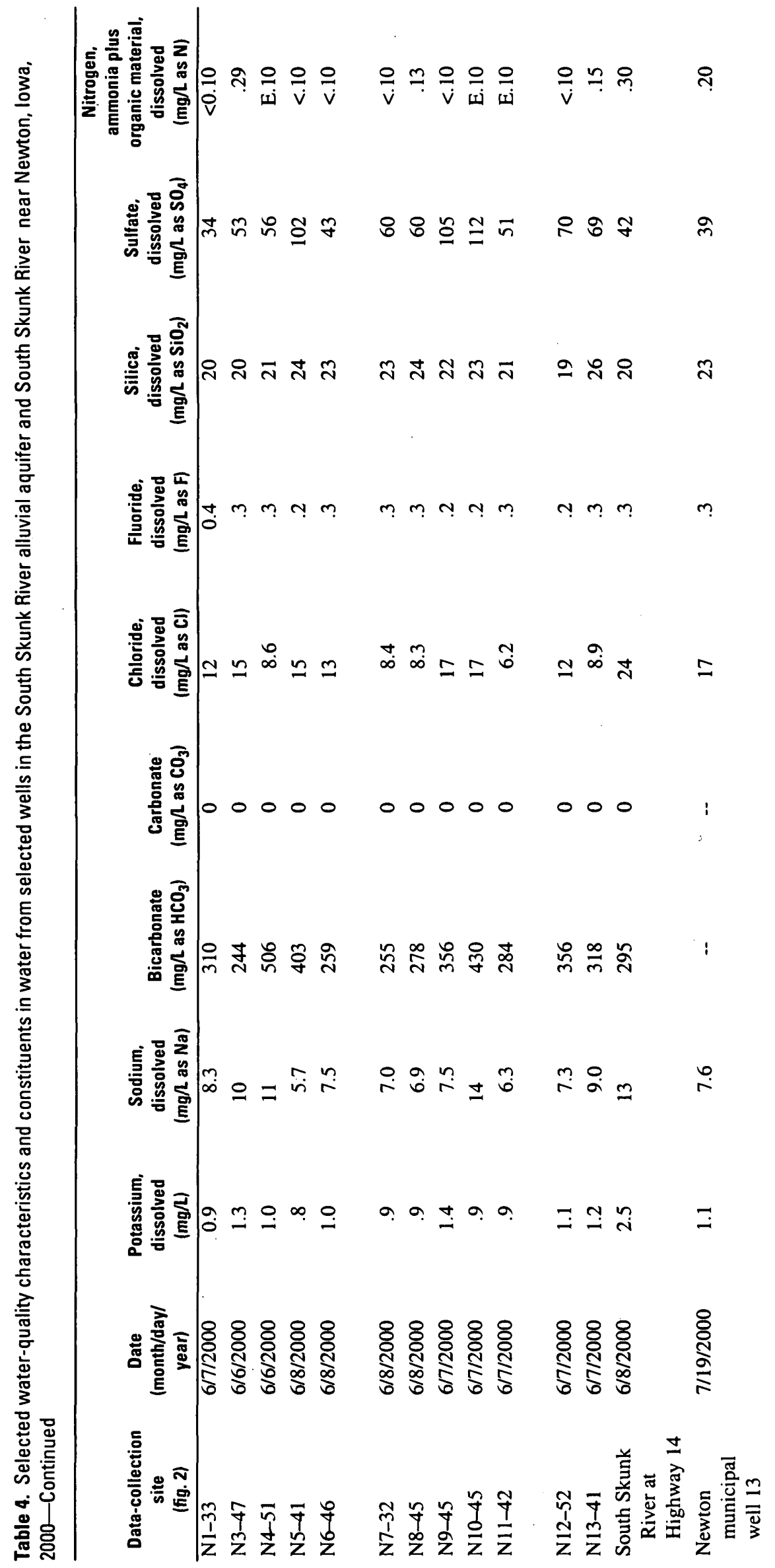




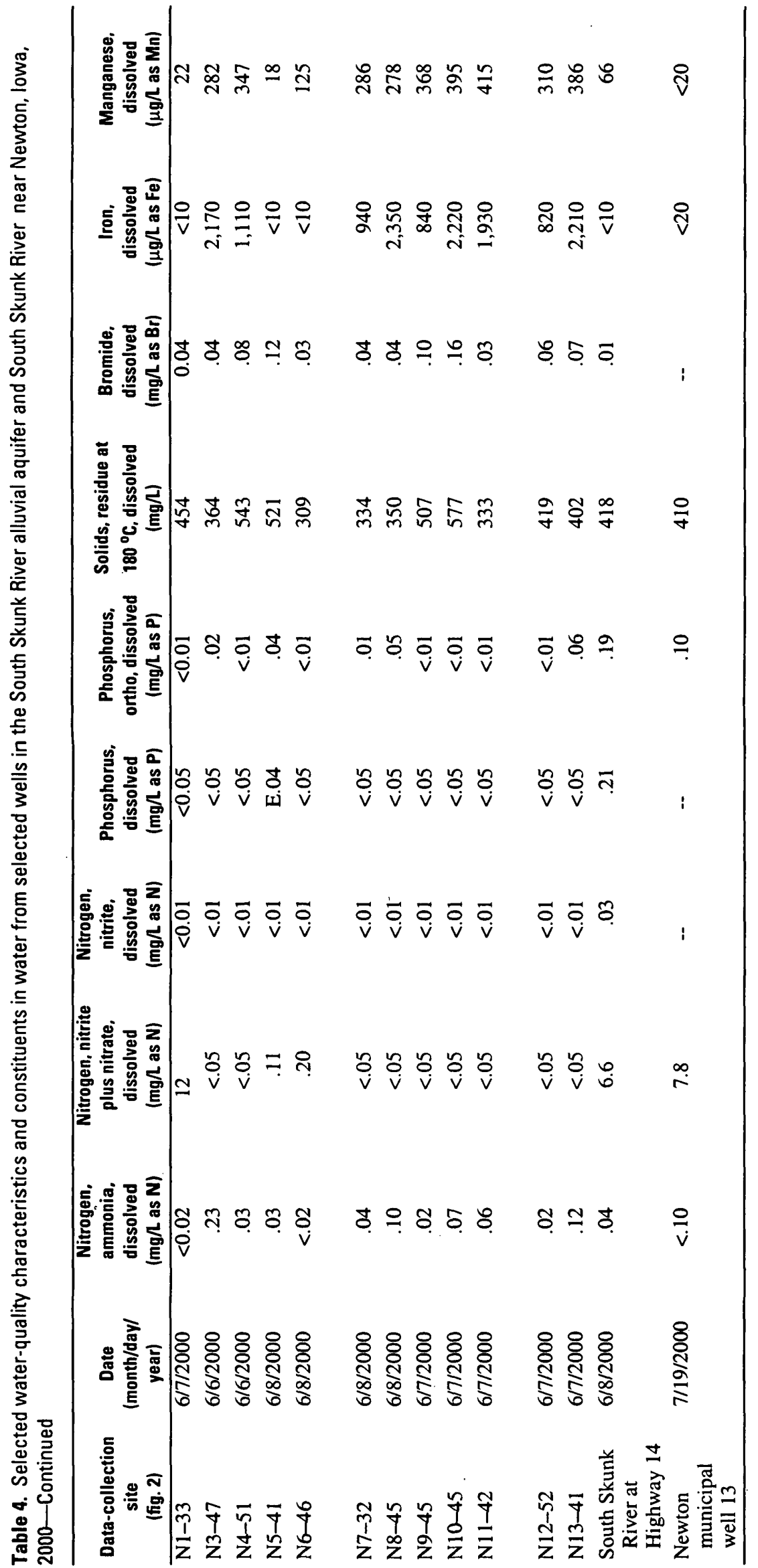

24 Ground Water Near Newton, Jasper County, lowa 
and manganese and large amounts of nitrate nitrogen. Water quality for city of Newton municipal well 13, sampled as part of a separate program, is also listed in table 4 for comparison purposes.

The cause of low dissolved-oxygen concentrations and the reducing conditions in the aquifer is not known. One explanation would be that the alluvial valley could be a regional discharge area for groundwater flow that upwells from bedrock into the alluvial materials. This discharge of deep, regional ground water would be expected to contain "old" water with little to no remaining dissolved oxygen. Norton and others (1912) report that wells drilled into the Mississippian aquifer beneath the South Skunk River Valley are artesian, with hydraulic heads from 10 to $20 \mathrm{ft}$ above the valley land surface. Wells drilled to the bedrock beneath the alluvial aquifer or additional alluvial wells at various depths would need to be installed to verify upward ground-water gradients beneath the valley and to confirm a discharge area of bedrock water.

A second explanation of the reducing conditions could be a biochemically driven reaction that is causing the denitrification of nitrate nitrogen with depth in the aquifer. The land use throughout and upgradient of the study area is mainly row-crop agriculture that utilizes substantial inputs of nitrogen fertilizer. As this nitrogen, predominately in the form of nitrate, infiltrates deeper in the aquifer, micro-organisms utilize the nitrate as part of their metabolism. These metabolic reactions result in reduced forms of nitrogen and low concentrations of dissolved oxygen. The low dissolved oxygen then causes oxidized forms of iron and manganese naturally present in the geologic materials to become reduced and mobilize into the dissolved phase. A source of organic carbon is needed to support these types of biochemical reactions. Well logs that describe coal, wood, and other buried vegetation indicate the presence of carbon in the aquifer to support these types of reactions.

\section{GROUND-WATER SOURCES IN THE JASPER COUNTY.AREA}

Hydrogeologic units underlying the Jasper County area (table 1) vary considerably in lithology, thickness, extent, and water-yielding capability. The primary ground-water sources are alluvial aquifers, glacial-drift aquifers, buried-channel aquifers, and bedrock aquifers.
The rate at which ground water can be withdrawn from wells in Jasper County is not only different for each aquifer but also can be different within each aquifer depending on location and local aquifer characteristics. Generally, the thicker the aquifer, the more water it will yield to a well. Alluvial aquifers will yield more water to wells on a sustained basis where the deposits are exposed at or near the surface and can be recharged by infiltrating precipitation or by surface water. Glacial-drift and buried-channel aquifers can have moderately high yields, but usually cannot sustain high pumping rates (greater than $300 \mathrm{gal} / \mathrm{min}$ ) because recharge to these deeper aquifers is limited by the water-transmitting characteristics of the overlying materials.

In areas where carbonate (limestone and dolomite) bedrock is near the land surface and is not covered by confining units, the rock may be highly fractured due to weathering and erosion prior to burial by youngeraged materials. Fractures in bedrock aquifers improve water-transmitting characteristics to wells.

In addition to well yield, water quality also affects whether ground water is used for human consumption. Naturally occurring minerals, such as dissolved solids and sulfate, limit the use of ground water in some areas either because of drinking-water regulations or for aesthetic reasons.

The aquifers that can consistently produce yields of sufficient quantity and that have acceptable water quality for municipal water supply in Jasper County include alluvial aquifers, the Mississippian aquifer, and the St. Peter and Jordan aquifers of the CambrianOrdovician aquifer system. Water from glacial-drift and buried-channel aquifers is used mainly by private, rural wells.

\section{Alluvial Aquifers}

Alluvial aquifers are the shallowest, and therefore most readily available, source of potential groundwater supply. Alluvial aquifers in Jasper County are composed of stream-deposited unconsolidated materials (mostly sand, gravel, silt, and clay) that occur in river valleys. Sand and gravel are the most permeable of the alluvial materials.

Two principal alluvial aquifers occur in Jasper County-one along the South Skunk River and the other along the North Skunk River (Bruner and Hallberg, 1987). The lithology and thickness of the South Skunk River alluvial deposits near Newton are 
described in the previous section of this report. Other smaller alluvial aquifers occur along Indian Creek and Elk Creek (Twenter and Coble, 1965).

Lithology and thickness of the alluvial aquifer in the South Skunk River Valley upstream and downstream from the study area is mostly unknown except from drillers' logs at a few well locations. That limited information does not indicate the presence of thicker alluvial deposits than those near the Newton well field. Information on alluvial materials along the North Skunk River, Indian Creek, and other streams in Jasper County is also limited. Alluvial materials along these smaller streams are probably thinner than those in the South Skunk River Valley and would have smaller water-yielding capabilities, except in locations where the alluvial aquifer might overlie a buriedchannel aquifer.

Twenter and Coble (1965) report yields from the South Skunk River alluvium to be greater than $500 \mathrm{gal} / \mathrm{min}$. A well in the Newton well field was pumped at a rate of $950 \mathrm{gal} / \mathrm{min}$ as part of an aquifer test ((Layne-Western Company, Inc., written commun., 1970). The greatest saturated thickness of sand and gravel in other alluvial aquifers (possibly as much as about $50 \mathrm{ft}$, locally) could produce yields of a few hundred gallons per minute to individual largediameter wells.

The water quality of the alluvial aquifers reflect the characteristics of water from wells that are completed in sand and gravel consisting mostly of siliceous materials of low solubility. Majors ions are calcium and bicarbonate, but sulfate and sodium are also important constituents. Hardness averages about $400 \mathrm{mg} / \mathrm{L}\left(\mathrm{CaCO}_{3}\right)$, and alkalinity averages about $250 \mathrm{mg} / \mathrm{L}\left(\mathrm{CaCO}_{3}\right)$. Concentrations of dissolved solids averaging about $500 \mathrm{mg} / \mathrm{L}$ are characteristic of water from alluvial aquifers in the South Skunk River Valley (Twenter and Coble, 1965).

\section{Glacial-Drift and Buried-Channel Aquifers}

Glacial-drift aquifers are composed of materials very similar to alluvial aquifer materials. The glacialdrift aquifers contain thin to moderately thick lenses of aquifer material that tend to be discontinuous and produce variable yields to wells. Glacial-drift and the possibility of aquifer material can be found over much of the upland area. Norton and others (1912) report that wells completed in loess and glacial drift in upland areas of Jasper County produce acceptable quantities and quality for private wells. These wells range from 25 to $300 \mathrm{ft}$ deep.

Ground water from the glacial-drift aquifers is of generally acceptable quality, but wells seldom yield large quantities of water except locally from thick layers of sand and gravel that may be present above the contact between the glacial drift and bedrock. Adequate information is not available to define the specific characteristics of these sources. Major ions are calcium and bicarbonate, but like the alluvial aquifers, sodium and sulfate are also common ions. Hardness averages about $375 \mathrm{mg} / \mathrm{L}\left(\mathrm{CaCO}_{3}\right)$, and dissolved solids average about $450 \mathrm{mg} / \mathrm{L}$ (Twenter and Coble, 1965).

Buried-channel aquifers are composed of alluvial materials deposited in bedrock valleys that have been covered by glacial deposits. Buried-channel aquifers can, but do not always, coincide with present stream valleys. Buried-channel deposits are difficult to locate because indications at the land surface normally are lacking (Olcott, 1992). Two major bedrock valleys were mapped by Hansen (1985) in Jasper County. One bedrock valley extends from east to west across the northern one-half of the county, whereas the other bedrock valley extends from east to west across the southern part of the county before turning northwesterly in the western part of the county. The thickness and type of materials filling these bedrock valleys and their water-yielding characteristics are not well known.

Ground water from buried-channel aquifers in central lowa is generally more highly mineralized than water from the alluvial or glacial-drift aquifers. Major ions are calcium and bicarbonate, hardness averages about $1,200 \mathrm{mg} / \mathrm{L}\left(\mathrm{CaCO}_{3}\right)$, and dissolved solids average about $2,000 \mathrm{mg} / \mathrm{L}\left(\mathrm{CaCO}_{3}\right)($ Twenter and Coble, 1965).

\section{Bedrock Aquifers}

Some bedrock units are sources of water, and some yield very little water. The bedrock units that yield water to wells are, in order of increasing depth below land surface, the Mississippian aquifer, the Silurian-Devonian aquifer, and the CambrianOrdovician aquifer system.

Bedrock of Pennsylvanian age discontinuously underlies surficial unconsolidated materials and consists primarily of shale, thin layers of sandstone, siltstone, coal, and possibly limestone. These rocks form a regional confining unit that in some areas 
separate overlying unconsolidated materials from the Mississippian aquifer. In some localized areas, a limited water supply can be developed in bedrock of Pennsylvanian age.

The natural chemical quality of water from the principal bedrock aquifers in Jasper County is highly variable. The chemical quality of ground water is affected primarily by the mineralogy of aquifer materials and the length of time that the water is in contact with these minerals (Olcott, 1992). Because concentrations increase along flow paths, ground water in outcrop and recharge areas is the least mineralized. Ground water in deep, confined aquifers where the water movement is slow tends to be the most mineralized.

The Mississippian aquifer is composed primarily of limestone and dolomite but can contain shale or evaporite deposits. The thickness of the Mississippian aquifer ranges from about 100 to more than $300 \mathrm{ft}$ in Jasper County, and well yields typically range from 20 to $50 \mathrm{gal} / \mathrm{min}$ (Twenter and Coble, 1965).

The quality of water from the Mississippian aquifer is highly variable, but the water generally is quite mineralized. Water from the Mississippian aquifer tends to be of the calcium bicarbonate type. The dissolved-solids concentrations can range from 2,000 to 3,000 mg/L (Olcott, 1992).

The Silurian-Devonian aquifer is separated from the overlying Mississippian aquifer by a thick, usually shale, confining unit. Although composed primarily of carbonate rocks (limestone and dolomite), the Silurian-Devonian aquifer may contain evaporite minerals, such as gypsum and anhydrite. Typical thickness of the Silurian- Devonian aquifer in Jasper County is about $600 \mathrm{ft}$ (Twenter and Coble, 1965). Well yields of less than $20 \mathrm{gal} / \mathrm{min}$ are estimated for most of Jasper County except near the western boundary of the county where yields increase to $20-50 \mathrm{gal} / \mathrm{min}$ (Twenter and Coble, 1965).

Evaporite deposits that occur locally in the Silurian-Devonian aquifer have a major effect on water quality. In areas where these minerals occur, degradation of water quality can be caused by high concentrations of sulfate, sodium, potassium, and chloride. Dissolved-solids concentrations in the Silurian-Devonian aquifer are in excess of $5,000 \mathrm{mg} / \mathrm{L}$ throughout most of Jasper County (Olcott, 1992). This naturally occurring poor water quality limits the use of water from the Silurian-Devonian aquifer.
The Cambrian-Ordovician aquifer system is a complex multi-aquifer system with individual aquifers separated by leaky confining units. In Iowa, the system is separated by a thick confining unit into an upper part, the Cambrian-Ordovician aquifer, and a lower part, the Dresbach aquifer (Olcott, 1992). The Cambrian-Ordovician aquifer system contains the deepest water-bearing units in Jasper County (Olcott, 1992). Sandstone in the upper part occurs from about 700 to $900 \mathrm{ft}$ below land surface (Twenter and Coble, 1965). The Dresbach aquifer contains saline water throughout most of Iowa and is not used extensively. Rocks in the lower part of the Cambrian-Ordovician aquifer system are not considered aquifers in central Iowa, so only aquifers in the upper part of the Cambrian-Ordovician aquifer system will be discussed.

The Cambrian-Ordovician aquifer, also referred to as the St. Peter-Prairie du Chien-Jordan aquifer, contains two sandstone aquifers, the St. Peter aquifer and the Jordan aquifer, separated by a unit composed predominately of dolomite, and is about $550 \mathrm{ft}$ thick in Jasper County (Twenter and Coble, 1965). In some parts of Iowa, the three units generally are hydraulically connected due to fracturing in the dolomite and function as one aquifer. The Jordan aquifer, ranging in thickness from 40 to $60 \mathrm{ft}$, yields more than $1,000 \mathrm{gal} / \mathrm{min}$ throughout Jasper County (Twenter and Coble, 1965). Ground-water flow in the CambrianOrdovician aquifer is generally southeasterly (Olcott, 1992). Primary recharge to the Cambrian-Ordovician aquifer is from vertical leakage (Burkart and Buchmiller, 1990). Declining water levels in this aquifer in some parts of Iowa are attributed to regional pumping rates exceeding recharge (Burkart and Buchmiller, 1990).

The water from the Cambrian-Ordovician aquifer is not as highly mineralized as that from parts of the Mississippian and Silurian-Devonian aquifers. Water from this aquifer generally is a calcium bicarbonate type and has hardness of about $300 \mathrm{mg} / \mathrm{L}\left(\mathrm{CaCO}_{3}\right)$, and dissolved-solids concentrations range from 500 to $1,000 \mathrm{mg} / \mathrm{L}$ (Twenter and Coble, 1965). Large concen. trations of iron, fluoride, and radium (Ra-266) (Horick and Steinhilber, 1978) are possible in water from this aquifer at some locations.

\section{SUMMARY}

The city of Newton obtains its municipal water supply from the South Skunk River alluvial aquifer. 
Withdrawals averaged $4.5 \mathrm{Mgal} / \mathrm{d}$ in 1998 , and additional sources of water may be needed by the city to meet an expected demand of $8 \mathrm{Mgal} / \mathrm{d}$ by 2007 .

To help address concerns about future sources of water supply, the U.S. Geological Survey, in cooperation with city of Newton, conducted a study to provide information about the sources of ground water (unconsolidated and bedrock aquifers) in Jasper County, particularly near the Newton area.

Available hydrologic and geologic information was compiled from the scientific literature and previous studies in the Newton area. Additional thickness and lithologic data for the unconsolidated materials in the South Skunk River Valley were collected for this study at selected sites from October 1999 through October 2000. Information on river stage and water quality in the South Skunk River alluvial aquifer near Newton also was collected.

The alluvial deposits along the South Skunk River Valley near Newton consist of sand and gravel deposits of glacial and fluvial origin. The sand and gravel are commonly interbedded with clay and silt lenses in the upper $20 \mathrm{ft}$ of the deposits. Deeper materials appear to be primarily sand and gravel. The upper bedrock beneath the alluvial aquifer consists of shale or limestone.

Seismic refraction and test-hole drilling were used to collect geologic information for the unconsolidated material in the South Skunk River Valley. Seismic refraction was used to determine the depth to bedrock below land surface and to estimate the thickness of unconsolidated materials. Test holes were drilled to determine the thickness and lithology of the unconsolidated material and to construct observation wells for measuring water levels and collecting waterquality samples.

Thicknesses of the unconsolidated materials in the South Skuilk River Valley in the study area range from less than 30 to more than $60 \mathrm{ft}$. Unconsolidated materials in three areas appear to exceed $50 \mathrm{ft}$ in thickness-an area about 5,000 ft west of the present well field, the present well field area, and an area about $5,000 \mathrm{ft}$ southeast of the present well field.

Water levels measured during 2000 indicate ground-water movement towards the Newton well field from within the alluvial aquifer. Water levels in the alluvial aquifer on the well-field side of the South Skunk River were lower than water levels in the river, indicating flow from the river toward the well field.
Water quality in the aquifer was similar to water quality in the South Skunk River except that most ground-water samples were low in dissolved oxygen. The reducing conditions in the aquifer resulted in high concentrations of iron and manganese and reduced forms of nitrogen.

\section{REFERENCES}

Bruner, D.R., and Hallberg, G.R., 1987, An overview of groundwater quality in the Skunk.River Basin: Iowa Department of Natural Resources-Geological Survey Bureau Open-File Report 87-3, 36 p.

Burkart, M.R., and Buchmiller, R.C., 1990, Regional evaluation of hydrologic factors and effects of pumping, St. Peter-Jordan aquifer, Iowa: U.S. Geological Survey Water-Resources Investigations Report 90-4009, 44 p.

Haeni, F.P., 1988, Application of seismic-refraction techniques to hydrologic studies: U.S. Geological Survey Techniques of Water-Resources Investigations, book 2 , chap. D2, 86 p.

Hansen, R.E., 1985, Bedrock topography of central Iowa: U.S. Geological Survey Miscellaneous Investigations Map I-1609, 2 sheets, scale 1:125,000.

Horick, P.J., 1984, Silurian-Devonian aquifer of Iowa: Iowa Geological Survey Miscellaneous Map Series No. 10, 4 sheets, scale 1:1,000,000.

Horick, P.J., and Steinhilber, W.L., 1973, Mississippian aquifer of Iowa: Iowa Geological Survey Miscellaneous Map Series No. 3, 3 sheets, scale 1:1,000,000.

1978, Jordan aquifer of Iowa: Iowa Geological Survey Miscellaneous Map Series No. 6, 3 sheets, scale $1: 1,000,000$.

Nalley, G.M., Gorman, J.G., Goodrich, R.D., Miller, V.E., Turco, M.J., and Linhart, S.M., 2001, Water resources data, Iowa, water year 2000: U.S. Geological Survey Water-Data Report IA-00-1, v. 1, 346 p.

Norton, W.H., Hendrixson, W.S., Simpson, H.E., and Meinzer O.E., 1912, Underground water resources of Iowa: U.S. Geological Survey Water-Supply Paper 293, p. 596-609:

Olcott, P,G., 1992, Ground water atlas of the United States, segment 9: U.S. Geological Survey Hydrologic Investigations Atlas 730-J, $31 \mathrm{p}$.

Prior, J.C., 1991, Landforms of Iowa: Iowa City, University of Iowa Press, $153 \mathrm{p}$.

Rimrock Geophysics, Inc., 1995, SIPT2V4.2, Seismic refraction interpretation programs: Lakewood, Colorado, Rimrock Geophysics, Inc., 56 p.

Twenter, F.R., and Coble, R.W., 1965, The water story in central Iowa: Iowa Geological Survey Water Atlas Number 1, 89 p.

U.S. Environmental Protection Agency, 1996, Drinking water regulations and health advisories: Washington D.C., Report 822-R-96-001, 16 p.

Williams, I.A., 1904, Geology of Jasper County: Iowa Geological Survey, v. XV, Annual Report, p. 277-367. 
